Portland State University

PDXScholar

5-19-1995

\title{
Through Women's Eyes: Contemporary Women's Fiction about the Old West
}

Anna Margarete Boettcher

Portland State University

Follow this and additional works at: https://pdxscholar.library.pdx.edu/open_access_etds

Part of the English Language and Literature Commons Let us know how access to this document benefits you.

\section{Recommended Citation}

Boettcher, Anna Margarete, "Through Women's Eyes: Contemporary Women's Fiction about the Old West" (1995). Dissertations and Theses. Paper 4966.

https://doi.org/10.15760/etd.6842

This Thesis is brought to you for free and open access. It has been accepted for inclusion in Dissertations and Theses by an authorized administrator of PDXScholar. Please contact us if we can make this document more accessible: pdxscholar@pdx.edu. 


\section{THESIS APPROVAL}

The abstract and thesis of Anna Margarete Boettcher for the Master of Arts degree in English were presented May 19, 1995 and accepted by the thesis committee and the department.

COMMITTEE APPROVALS:
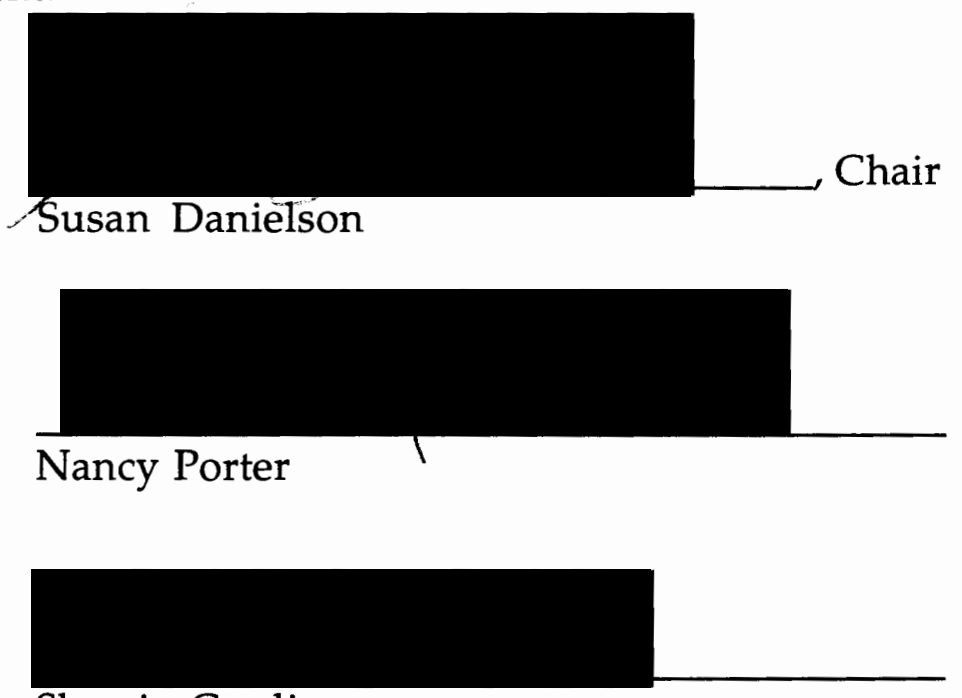

\section{Sherrie Gradin}

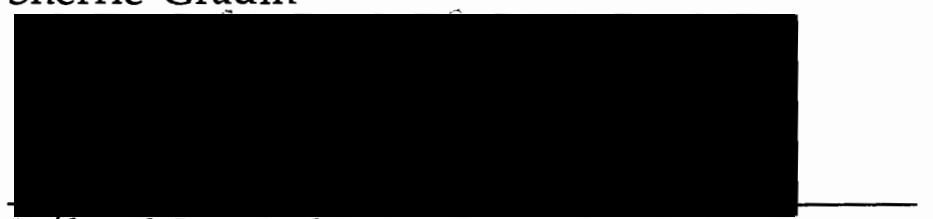

Richard Wattenberg

Representative of the Office of Graduate Studies

DEPARTMENT APPROVAL:

Shelley C. Reece, Chair

\section{ACCEPTED FOR PORTLAND STATE UNIVERSITY BY THE LIBRARY}




\section{ABSTRACT}

An abstract of the thesis of Anna Margarete Boettcher for the Master of Arts in English presented May 19, 1995.

Title: Through Women's Eyes: Contemporary Women's Fiction about the Old West.

The myth of the West is still very much alive in contemporary America. Lately, there has been a resurgence of new Western movies, TV series, and fiction. Until recently the West has been the exclusive domain of the quintessential masculine man. Women characters have featured only in the margins of the Western hero's tale. Contemporary Western fiction by women, however, offers new perspectives. Women's writing about the Old and New West introduces strong female protagonists and gives voice to characters that are muted or ignored by traditional Western literature and history.

Western scholarship has largely been polarized by two approaches. First, the myth and symbol school of Turner, Smith, and followers celebrated American exceptionalism and rugged male individualism on the Western frontier. Second, the reaction against these theories draws attention to the West's legacy of racism, sexism and violence. The purpose of the present study is to collapse these theoretical fences and open a dialogue between conflicting theoretical positions and contemporay Western fiction. Molly Gloss's 1989 The Jump-Off Creek and Karen Joy Fowler's 1991 Sarah Canary selfcritically re-write the Old West. 
This study has attempted to explore the following questions: How can one re-write history in the context of a postmodern culture? How can "woman," the quintessential "Other" escape a modernist history (and thus avoid charges of essentialism) when she has not been in this history to begin with?

In this study I analyze how these two contemporary feminist authors, Molly Gloss, and Karen Joy Fowler, face the dual challenge of writing themselves into a history that has traditionally excluded them, while at the same time deconstructing this very historical concept of the West. Fowler's and Gloss's use of diverse narrative strategies to upset a monolithic concept of history-- emphasizing the importance of multiple stories of the Old West-- is discussed in detail. 
THROUGH WOMEN'S EYES:

CONTEMPORARY WOMEN'S FICTION ABOUT THE OLD WEST

by

ANNA MARGARETE BOETTCHER

A thesis submitted in partial fulfillment of the requirements for the degree of

\author{
MASTER OF ARTS \\ in \\ ENGLISH
}

Portland State University

1995 


\section{ACKNOWLEDGEMENTS}

I particularly want to thank my Thesis Advisor Sue Danielson for her time, patience, and encouragement. Marcia Silver deserves special gratitude as well for generously lending me her computer over the past two months, and also for chairing the Thesis Support Group, whose members Cheri Buck-Perry, Debra Z. Gahlhoff, and Gina Eastman have contributed much to my insights. I especially thank my friend Gina Eastman for combining theory with practice. She gave much of her time, energy, and love to my work. I also want to thank Lorraine Mercer for letting me use her house, her bathtub, her garden, and her computer in the finishing stages of my text. Shelley Reece, Nancy Porter, Sherrie Gradin, and Richard Wattenberg were critical and supportive readers of my thesis. Ben Marlow has helped by lending me his car. I wish to thank my friend and house mate Heather Angell for numerous acts of kindness.

Finally, I am most grateful to Molly Gloss and Karen Joy Fowler who kindly agreed to let me interview them. Their support and interest in my work inspired me greatly. 
TABLE OF CONTENTS

PAGE

ACKNOWLEDGMENTS $\ldots \ldots \ldots \ldots \ldots \ldots \ldots \ldots \ldots \ldots$ ii

PREFACE $\ldots \ldots \ldots \ldots \ldots \ldots \ldots \ldots \ldots \ldots \ldots \ldots \ldots \ldots \ldots \ldots \ldots \ldots \ldots \ldots$

CHAPTER

I DANCING ON THE FRONTIER $\ldots \ldots \ldots \ldots \ldots \ldots \ldots \ldots$

Myth and Symbol School.................. 6

Revision......................... 10

New Paradigm $\ldots \ldots \ldots \ldots \ldots \ldots \ldots \ldots \ldots \ldots \ldots \ldots \ldots \ldots \ldots$

II JUMP-OFF POINTS $\ldots \ldots \ldots \ldots \ldots \ldots \ldots \ldots \ldots \ldots \ldots \ldots$

Reversal on Character and Plot Level ........... 23

Structural Strategies ................... 27

Language in the West .................. 35

III MULTIVOCAL CANON $\ldots \ldots \ldots \ldots \ldots \ldots \ldots \ldots \ldots \ldots, 42$

Rethinking Concepts .................. 43

Discourse Layers ...................... 45

De-Sanitizing Sanity $\ldots \ldots \ldots \ldots \ldots \ldots \ldots \ldots \ldots$

Language and Perception................ 50

The Act of Storytelling. . . . . . . . . . . . . . 53

IV LIVING IN THE WEST $\ldots \ldots \ldots \ldots \ldots \ldots \ldots \ldots \ldots \ldots . \ldots \ldots$

NOTES ..................................... 69

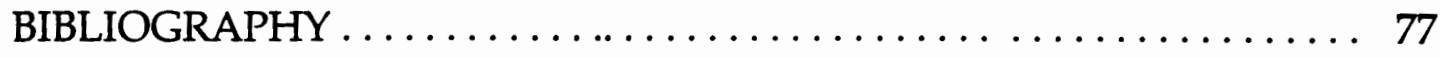




\section{PREFACE}

\section{"HOW I CAME TO THE WEST AND WHY I STAYED"1}

My interest in this project of Western fiction developed out of my adolescent experience. Growing up on the outskirts of Munich in Germany, I was nevertheless exposed to Western literature and movies early on. I quickly began to love Western stories; partly because my parents are film buffs, and talk intelligently about the various classic Western film directors such as Wyler, Wellman, Ford, Hawks, and others, and partly because the clear-cut Western stories are especially appealing to an adolescent mind. I remember watching my first movie ever (officially, at least), the classic High Noon, and spending at least half of the time hiding behind the living room curtains because I was not used to all this "don't forsake me, oh my darling" shoot-out drama. Reading the entire works of Laura Ingalls Wilder was another forming influence. There I had the two classical opposites: the man's story and the woman's story. In Little House on the Prairie, Ma's only comment to her husband's never-ending desire to go further West was "Oh Charles!" I couldn't understand this attitude. How could she say something as insipid as that? What about her sense of adventure? What was wrong with going further and further West? Ma's desire to settle down, to build a home and stay in it, to send her daughters to school and church did not make any sense to me. Another influence, and crucial for my coming to Oregon, was An Rutger's children's adventure story Children on the Oregon Trail in which a group of children 
cross the Rocky Mountains by themselves after their parents' death on the road.

When I was sixteen, my desire to go West was displaced by a desire to go East. Reading novels about Siberia, I was for quite some time convinced that Siberia was the last and only frontier that could make an adventurous spirit like myself happy. And when I finally left home, I did not go West, or East, but instead North to Scotland. That suited me well enough however, because Scotland is sparsely populated and has a dramatic landscape. Losing and finding myself in the Scottish Highlands did not prove to be too difficult. After going back again to Germany, I longed for the space and eerie lights of Scotland. When I finally decided to go to America for my studies abroad, I was very sure of where I wanted to go: to the West Coast, to Oregon, preferably--the promised land. I needed to go as far away from home as possible. I wanted to go to the Wild West, but to do what? To find gold? To fight Indians? No, of course not. My childhood days of sitting in a silly plastic imitation tee-pee to play the "submissive Squaw" were fortunately over.

Once in Oregon, I discovered that there really is something to the myth of the West, something that is better than all the TV versions of cowboymeets-schoolmarm dramas. When I went East of the Cascade Mountains for the first time, I had an epiphany: I saw my first real live mesa rim and my subconscious expected the silhouette of Indians to line up against the horizon. I was surprised how strongly the popular version of the mythic West was ingrained in me. My background in Western fiction and film had very much colored my experience of the actual, geographical West. I had to admit that film influences nature, not the other way round. I 
realized that the West is dream land. It is seductive in its sheer space; it promises adventures, but not to all Westerners equally.

Reading Jane Tompkins's influential study West of Everything, The Inner Life of Westerns, taught me to look more closely at who does the talking, or who has the power in traditional Westerns. I have to agree with Tompkins that in traditional Westerns women do most of the talking, but they talk in vain. Grace Kelly in High Noon is a classical example. She unsuccessfully tries to talk her new husband Gary Cooper into leaving town (and thereby avoid getting shot by his opponents), but he tells her in very few words that a "man's gotta do what he's gotta do," meet his enemies. My dissatisfaction with the female Western protagonists grew when I was repeatedly confronted with having to choose between the tame, upright schoolmarm and the tainted woman (who at least had some sexual power). This frustration over the classical opposition of virgin and whore lead to more research and, paradoxically, to a greater love of Western film and fiction, because it lead me off the beaten track to look into the nooks and crannies of Western writing. Taking a class in Western American Literature with writer Molly Gloss further confirmed where my interests really lie: women's Western literature, old and new.

I chose Molly Gloss's The Jump-Off Creek and Karen Joy Fowler's Sarah Canary for this thesis because both novels convinced me that Western American literature is much more than the sound of horse hooves drumming on the desert ground, or the sumburnt face of a cowboy riding into the picture. Also, and I am a little ashamed to admit it, I was intrigued by the fact that virtually nothing had been written about these novelists yet. I felt like a true pioneer, and once again succumbed to the power of the 
Western myth. At any rate, Western American literature is alive and well, partly because these two women are writing their stories into the widened can(y)on of the West. 
CHAPTER I

\author{
DANCING ON THE FRONTIER: \\ SPECULATIONS IN CONTEMPORARY THEORY OF THE WEST
}

\# 58: Only as Creators!--This has given me the greatest trouble and still does: to realize that what things are called is incomparably more important than what they are. The reputation, name, and appearance, the usual measure and weight of a thing, what it counts for--originally almost always wrong and arbitrary, thrown over things like a dress and altogether foreign to their sense and even to their skin--all this grows from generation unto generation, merely because people believe in it, until it gradually grows to be part of the thing and turns into its very body. What at first was appearance becomes in the end, almost invariably, the essence and is effective as such.

What a fool one would have to be to suppose that it is enough to point out this origin and this misty shroud of delusion in order to destroy the world that counts for real, this so-called "reality." We can destroy only as creators--But let us not forget this either: it is enough to create new names and estimations and probabilities in order to create in the long run new "things."

Friedrich Nietzsche The Gay Science

Western theory 2 has largely been polarized by two approaches to the American West. On the one hand we find the myth and symbol school, as introduced by Western historian Frederick Jackson Turner in 1893 and cultural critic Henry Nash Smith in 1950, on the other hand we find revisionist theories about the West that react against the ideas put forth by Turner and his followers. What Western theory has lacked so far is a critical treatment of its own terms. Only in recent years has a new critical 
awareness arisen that cautions against an unquestioned use of concepts such as "frontier" and the "West". Poststructuralist 3 thought has influenced this new critique of Western theory as it self-consciously reflects on its own method of inquiry. With that in mind, terms such as "frontier" and "West" are no longer stable, true terms, but rather approximations, umbrella terms that inhabit multiple interpretations. This different, that is, self-conscious epistemological criticism in Western theory makes way for a new Western fiction to come into existence: postmodern Western novels by women who write about the Old West, ${ }^{4}$ Nietzsche, whose ironic reflections on the genealogy of the West have strongly influenced postmodern points of departure, rightly points out that it is only by creating new "things" that one can get rid of old deceptions. Similarly, it is this new literature that these women authors write that makes possible a change in the persisting Western paradigm--it creates new "things." Before discussing Molly Gloss's Jump-Off Creek and Karen Joy Fowler's Sarah Canary, I want to outline my theoretical basis and, with that, trace the recent changes that inform new possibilities as they manifest in contemporary Western fiction. In order to assess recent Western theory, it is useful to historicize the more canonical Western theories.

\section{The Myth and Symbol School}

Frederick Jackson Turner, one might say, is the original Marlboro 5 man of Western theory: his famous frontier thesis, formulated in his 1893 article "The Significance of the Frontier in American History," states that "the frontier is the meeting point between savagery and civilization" (200). 
It is the place where the European immigrant is confronted with the American wilderness, and with the animal of that wilderness--the American Indian. Civilization meets savagery, and from this confrontation springs the new American who learns to shed his European clothes, and takes on the Indian costume without entirely "going native." 6 Thus he is reborn as the civilized American, and now stands as the heroic ancestor of the contemporary American man who finds comfort in the grandeur of this genealogy. Turner's frontier thesis is nothing less than a creation myth; it is an attempt at a national epic. ${ }^{7}$ America, struggling to wean itself from the patronizing clutches of the materialist Old World (Europe) since the seventeenth century, embraces the idea of the West in which the American man finds his true identity. The West comes to symbolize the ultimate difference that distinguishes America from Europe. The vast, unknown wilderness beyond the Western frontier is the place where the new paradise is about to fulfill itself. Like the later Marlboro man, Turner has influenced generations of Americans in their understanding of what America is, and has determined the role the West plays in this cultural autobiography. Like the image of the Marlboro man, Turner's approach to the West is seductive but narrow. At closer inspection, the rugged individualism turns out to be the dress for an ethnocentric, nationalistic, and sexist state of affairs. Turner completely ignores the role women play in the development of the West, he belittles the participation of American Indians, and he mythologizes the "peaceful westward expansion" (200).

The advertising strategy of the Marlboro commercial is similar to Turner's approach to the West: one small part of the West comes to 
represent the whole of the West. The traditional cowboy in the Marlboro commercial who interestingly enough replaced the earlier female target for this cigarette, has long been replaced by machines, fences, and pick-up trucks in the real, geographical West. Nevertheless, the image of the cowboy who is alone with his horse and his cigarette, alone and at one with the wilderness around him, still stands for freedom and masculine individuality. The myth of freedom, independence, individuality, and intellectual pensiveness (represented by the cigarette) is strangely reversed in the more material world. Here people often smoke because it helps them numb the pain that emanates from the subtle cruelty of their reality, a reality in which the fastest growing number of smokers are young women. Again, it is ironic, that the original Marlboro cigarette was targeted at women, but did not sell. The myth of the masculine individualist seems to be more appealing. Turner's frontier thesis that has influenced generations of Western scholars, as well as popular culture, was further promoted by his follower Henry Nash Smith, who in his 1950 study Virgin Land solidified Turner's mythology of the West into facts.

Smith's study of the West is a reaction against modernism, and laments the advent of science, urbanization, and industrial agriculture in the West. Smith's aim is to contextualize the popular tradition of America as pastoral paradise in which the yeoman farmer reigns supreme, envisioned by such early writers as St. John De Crèvecoeur's Letters From an American Farmer. 8 In tracing the impact of the West, "the vacant continent beyond the frontier, on the consciousness of Americans," (4) Smith insists that the tradition of the "myth of the garden" (251) is the central influence on Turner's frontier thesis. ${ }^{9}$ Smith naturalizes Turner's 
frontier thesis by putting it into its historical context. He claims that Turner's persuasive frontier thesis "could hardly have attained such universal acceptance if it had not found an echo in ideas and attitudes already current" (4). He points out that "myth of the garden" voiced by Turner and followers does not translate to a post-agrarian, industrial and urban America. In fact, Smith postulates that Turner's "myth of the garden" posits some real dangers for Americans, political as well as social, because Americans consequently fail "to think of themselves as members of a world community" (260). More than thirty years after the publication of his famous book, Smith acknowledges in an essay entitled "Symbol and Idea in Virgin Land " that he took over from Turner an attitude characteristic of American culture, a refusal to acknowledge the guilt intrinsic to the national errand into the wilderness"(23). Now he admits that "an American ideology is constantly present in Virgin Land but offstage, so to speak, only occasionally given explicit recognition." This American ideology of Manifest Destiny ignored the importance of Native Americans, the legacy of violence, racism and environmental abuse. Smith concludes: "Like my teachers and academic colleagues, I had in this fashion lost the capacity for facing up to the tragic dimensions of the Westward Movement" (27-29).10 Numerous other scholars have criticized Smith for idealizing American exceptionalism. If one considers for example, that Smith's influential book was written after WW II, its nationalistic overtone is especially disturbing. 
$\underline{\text { Revision }}$

This romantic idealism of Turner and Smith collapses with the advent of the Vietnam War. Now begins a series of social and political crises spear-headed by the Civil Rights Movement in the late sixties and the Women's Movement in the early seventies. America, and with it the American West, falls from its self-made grace, so to speak, hits the ground, and wakes up bruised and in need of cultural redefinitions that offer alternatives to the unhappy predominance of a masculine Anglo-Saxon idea of history.

In reaction to this, two trailblazing Western scholars, Kolodny and Slotkin, take a stand in binary opposition to Turner and Smith. Annette Kolodny, as well as Richard Slotkin, now undertake to re-write Turner's and Smith's myth of the West by looking at how previously unheard voices--the voices of women and ethnic minorities change the history and the story of the West. Kolodny's feminist ${ }^{11}$ books, The Lay of The Land and The Land Before Her, as well as Slotkin's cultural critiques, Regeneration Through Violence and The Fatal Environment, symbolize a turning point in Western theory. Kolodny, as well as Slotkin, clearly react against Turner's and Smith's notions of a "peaceful westward expansion. They claim that Henry Nash Smith's 1950s Virgin Land was not a virgin land at all, thereby pointing out the obvious, namely that the original inhabitants, the Native Americans, were already there. Moreover, they take account of the fact that the Native Americans were forcefully and violently pushed off their land in order for the "peaceful" westward expansion" of the white settlers to come true. Slotkin's main point in The 
Fatal Environment is that the agrarian myth served as a "displacement or deflection of social conflict in to the world of myth" (17). In The Lay of the Land , Kolodny claims, that Smith's embellishing metaphor of the "virgin land" implies the view of the land as female in order to justify its domination and exploitation. Women's roles in settling or unsettling the West were, according to Kolodny, never adequately studied. In her second book, The Land Before Her, she points out that women's "fantasies" of the Western frontier differed radically from men's visions of the frontier. For Kolodny, women were less interested in conquering and subjugating the West, and its original inhabitants were less interested in mythic, epic, and heroic feasts, but instead were more occupied with practical daily deeds, such as cultivating the land and turning the wilderness into a domestic garden. 12 Both Slotkin and Kolodny aptly analyze the West's legacy of racism, ethnocentrism, and violence.

However, my aim here is not to continue the diametrically opposed show-down between Turner and Smith on the one hand, and Kolodny and Slotkin on the other. That would imply the raising of another theoretical fence, it would support a structuralist binarism that is not necessarily helpful. Nor is my aim to construct a progressive line of Western theory that moves from the savagery of the myth and symbol approach in Western theory to the civilization of enlightened skepticism of postmodern revisionist theories-- a more advanced form of cultural imperialism, I would argue. Henry Louis Gates Jr. points out in his recent article "Master's Pieces: On Canon Formation and the African-American Tradition": 
Academic critics write essays, "readings" of literature, where the bad guys (for example, racism or patriarchy) lose, where the forces of oppression are subverted by the boundless powers of irony and allegory that no prison can contain, and we glow with hard-won triumph. We pay homage to the marginalized and demonized, and it feels almost like we've righted a real-world injustice. (97)

No, the aim here is not to create a new "good guy," a postmodern avenger of the disenfranchised. Rather, the potential for a creative and critical moment lies in the deconstruction of the artificial fences between the different theoretical camps (Nietzsche's "misty shrouds of delusion"). Now with those fences down a space opens up for a new dialogue around concepts of the frontier, of the American West, and the significance of the discourse of the West in Western American literature and history in relation to its self-critical reflection on its own underlying assumptions. 13

\section{The New Paradigm}

While Kolodny and Slotkin have sparked an important new discussion, much can be criticized in their work. In his article "After Turner and Smith: Recent Interpretations of the American West as Symbol and Myth," Rudolf Erben, a German Americanist, argues that Kolodny and Slotkin fall into the same methodological trap that Turner and Smith got caught in. He points out that Kolodny idealizes women's fantasies of the West in much the same way as Turner and Smith have glorified men's visions of the West, whereas Slotkin's notion that Americans projected their urban and industrial conflicts on an unknown territory and unfamiliar race 
affirms the dialectic interaction between reality and myth. Other critics have criticized Kolodny and the rewriting of Western history for Kolodny's lack of geographical awareness, or even more radically for Kolodny's use of written sources only. 14 At the same time one might argue, of course, that Erben's own style of thinking about Western theory, that is, his pointing back towards Turner and Smith as meta-theories about the West, in itself solidifies this self-fashioned genealogy of canonical theory. In any case, all these different Western critics, ranging from scholars such as Slotkin and Kolodny to lesser known regional scholars like Milton and Athearn, however dissimilar their approaches may be, make an effort to expand the notion of the West by drawing attention to the diversity within the (still) unifying national epic.

Three contemporary Western theorists, Patricia Nelson Limerick, Jane Tompkins and Annette Kolodny undertake a clear paradigm shift in terms of their methodology. Patricia Nelson Limerick'sThe Legacy of Conquest. The Unbroken Past of the American West," Kolodny's recent essay "Letting Go of Our Grand Obsessions: Towards a New Literary History of the American Frontiers," and Jane Tompkins's West of Everything.The Inner Life of Westerns reflect contemporary post-structuralist influences through the ways in which they interrogate the study of the West and the language it uses to describe and prescribe the West.

Before I comment on language, I want to take a look at the difference in method we can find here. Patricia Nelson Limerick rejects the underlying paradigmatic assumptions of Kolodny's and Slotkin's earlier studies which at that time continued to cling to the ontological truth about a presumably progressive hegemony of the West. In her 1987 revisionist history of the 
West The Legacy of Conquest, Limerick concentrates on the study of the West as place, as region. 15 Interestingly enough, she does not focus so much on the deconstruction of the myth of the frontier, as she does on the activity of writing the daily lives of ordinary people like women and ethnic minorities. She replaces the Western genealogy of great men and great events with a history of the Other. This departure from traditional Western history takes a distinct step towards a New Historicist ${ }^{16}$ approach to the culture of the West that unearths the subjectivity of traditional historical truth claims. Limerick points out that the history of America is rooted in the concept of slavery and conquest. She further proposes that, whereas the legacy of slavery was taken seriously by historians, the legacy of conquest was not. Limerick reasons that the idea of conquest is still a popular one--as depicted in stories, films, and cyberspace metaphors of popular culture--because the concept of the conquest of the West still offers a valuable escape mechanism for Americans who are faced with a frustrating, adventureless, and quietly desperate reality. ${ }^{17}$ Limerick's work de-emphasizes the concept of the frontier, and emphasizes instead the diversity of the region of the West: now the West is not only the arid desert landscape of Northern Arizona, but also other landscapes less typically associated with the West like the urban ghetto of Los Angeles, for example.

With that, Limerick critically questions the concept of the frontier itself as it was used by the myth and symbol school as well as by the reactions against it through Kolodny and Slotkin. She suggests that the concept of the frontier is a loaded one. It implies a questionable belief in progress that reinforces a linear historical development, and thereby excludes other, 
perhaps non-dialectical concepts. Limerick questions the revision of the Turnerian concept, not only by emphasizing what Turner and colleagues did not mention in their studies of the West, but by problematizing the language of the West, the language concept of the frontier. What I like about Limerick's work is that she draws the past into the present. I agree with her when she says that the American frontier is not closed but reopened at every lawsuit concerning water, land, or fishing rights between Native Americans and white Americans. Western history then is not only a matter of theoretical discussion, but also a matter of practical negotiations. The decisions and contracts made one hundred years ago still affect the way people live today. Likewise, the desires people theorized about the West in the 1890s still affect Western scholarship today. It is not surprising, I think, that the study of the American West is popular in Germany and other European countries. The American West still functions as a powerful myth for people's dreams of freedom and boundless opportunities. The separation between theory and practice is artificial if one considers that every Westerner has to come to terms with the popular myth of living in the West.

In her more recent article "Letting Go of Our Grand Obsessions: Notes towards a New Literary History of the American Frontiers," Kolodny makes a similar point. She now argues for a radical re-definition of the concept of the frontier which will result in a re-imagining of Western theory and Western American literary criticism in general. Kolodny acknowledges--thereby implicitly critiquing her earlier works--that the concept of the Western American frontier has dominated the field of frontier literature. To study the frontier and frontier literature has always 
meant to study the dominant culture, i.e. the Anglo-American culture's penetration of the Western American territory that displaced or even exterminated the original inhabitants, the Native Americans. With this article Kolodny is moving even further away from an ethnocentric AngloAmerican phallocratic perspective of the study of the Western American frontier and the American West towards a more comparativistic, allinclusive, multi-lingual, multi-cultural approach to the study of multiple frontiers of many "others." With that, the concept of frontier is displaced and transformed into something other than geography or modernist history. Even though she does not quite know what this other is, or what its name would be, it can be said that Kolodny creates this chaos of concepts in the hope of finding a break in the conventional time/space continuum of old historicism to define a moment of vision for a new epistemology of the term frontier which will result in a "more inclusive interdisciplinarity" (2). She postulates:

To effect this project will require that we let go our grand obsessions with narrowly geographic or strictly chronological frameworks and instead recognize "frontier" as the locus of first cultural contact, circumscribed by a particular physical terrain in the process of change because of the form that contact takes, all of it inscribed by the collisions and interpenetrations of language. (3)

Clearly, Kolodny replaces the single focus on one Western American frontier with a multiplicity of first encounters between various cultures and many languages. She explains that "there can be no paradigmatic first contact because there are so many different kinds of first encounters. And there can be no single overarching story" (13). If the meta-history of the 
West 18 is then unveiled as nationalistic enterprise that privileges one region and one literary concept over another, the question can no longer be "who was not included?" or, "who are the bad guys?" At least as interesting is the interrogation into the structure of the Foucauldian force relationships that resulted in privileging one theoretical approach over another in the field of Western studies.

Limerick and Kolodny both suggest that the concept of the frontier, and with it the traditional reading of the American West, is problematical if one takes seriously theoretical impulses such as poststructuralist and late feminist theories that are interested in comparative approaches, in difference, in the spaces in between deceptive coherences. Turner's concept of the frontier as receding line against savagery can be better understood, perhaps, as a different kind of borderland. Maybe it is nothing but a meeting place for a linguistic geography. According to Kolodny, language takes on a new significance in the study of the frontiers because it is through language and its multiplicity of meanings that the different cultures try to make sense of each other, influence and learn from each other, or misunderstand each other. The critics of frontiers can make sense of the frontiers only through language. Since all we have is the text, Nietzsche's aphorism \# 58 is encouraging: "it is enough to create new names and estimations and probabilities in order to create in the long run new 'things.'" Kolodny pleads for a multi-lingual approach to the study of frontiers, thereby displacing the critically privileged language of the dominant discourse to the languages of previously ignored discourses.

An example of how recent Western theory has affected a particular field of Western culture is Jane Tompkins's West of Everything:The Inner Life 
of Westerns, in which she interrogates the persisting popularity of Western movies. She is interested in why Western fiction, and later Western movies, became so popular in the early twentieth century, and how the power relationships between men and women are played out in terms of language. 19 In traditional Western film, the silent male hero is powerful, the talkative woman functions as the subordinate helpmate. The language of the Western is carefully scrutinized in Jane Tompkins's study. She argues that what is true for the genre of Western film and literature is also true for the genre's treatment of language:

What is most characteristic of these oppositions [male/female, East/West, language/action] is that as soon as you put pressure on them they break down. Each time one element of a pair is driven into a corner, it changes shape and frequently turns into its opposite. (48)

Different from the disciples of coherence, Tompkins's analysis of Western movies concentrates more on the contradictions that are alive within the genre of the Western. She is intrigued by the way the force relations between oppositions such as male/female, East/West, language/action play out in the Westerns, and how these oppositions collapse in order to leave gaps and indeterminacies in the viewers' minds.

It's as if the genre's determination to have a world of absolute dichotomies ensures that interpenetration and transmutation will occur.(...) Time and again they [Westerns] set up situations whose message is that words are weak and misleading, only actions count; words are immaterial, only objects are real. But the next thing you know, someone is using language so brilliantly, delivering an epigram so pithy and dense it might as well be a solid thing. (48/49) 
Westerns, according to Tompkins, perpetuate the dominant Western paradigm of the silently suffering and at the same time silently powerful Western hero, who fights against the advent of Eastern culture--often represented by a civilized woman--and the bad guy. Her study of the Western does not only concern itself with individual movies, but draws connections between the feminine literary climate of the nineteenth century and the overtly violent climate of the twentieth century. Tompkins opens the discussion of Westerns to an interdisciplinary realm.

What these three Western theorists have done is to self-consciously question the study of the West by unraveling the epistemology of Western theory and history. These new rewritings of Western theory affect the way we think and write about the West, and ultimately influence how we live in the West. Theory affects practice. Those who want to destroy old paradigms must be bodacious enough to create new ones. In her influential 1964 article "Against Interpretation," Susan Sontag already argues for a poetics of culture as an alternative to the slavery of interpretation. In the same spirit, I think that the two contemporary novels that I choose to talk about in the following chapters represent a poetics of culture, a creative way of thinking about Western theory and practice. Molly Gloss's novel, The Jump-Off Creek, as well as Karen Joy Fowler's novel, Sarah Canary, re-envision the history of the Old West by offering a new cast of characters--consisting of the previously underrepresented voices of women, ethnic minorities, and the mentally disturbed. Their subjective histories surprise readers' notions about the conventions of traditional Western fiction; by altering their narrative strategies these authors upset the old notions of the Western shoot-out plot. Gloss and 
Fowler tell stories in which the typically Western oppositions of language and action transform into unfamiliar potentialities. 
JUMP-OFF POINTS FOR AN ALTERNATIVE WESTERN STORY:

MOLLY GLOSS'S THE JUMP-OFF CREEK

OR:

THE NEED TO CONNECT IN THE WEST

"In the room the women come and go

Talking of Michelangelo."

Eliot, The Love Song of J. Alfred Prufrock

"When the women came into the parlor there was a general softening of voices, a falling off of talk."

Gloss, The Jump-Off Creek, 143

The myth of the West is "still alive and well"20 at the end of the twentieth century. Although much has changed since the first enthusiasm over Owen Wister's classic Western, The Virginian, the West continues to fascinate readers and writers alike. In recent years a new group of writers has devoted its attention to the study and portrayal of the West. Women writers, long excluded from canonical literature, have forged their way into what has been for the longest time a strictly male terrain: Western American literature. 21 Now, in the late 1980s and early 1990s, one can sense a new literary movement growing stronger and stronger.

Contemporary women writers are writing themselves into the West, the Old as well as the New West. In the following chapter I will discuss The Jump-Off Creek, Molly Gloss's 1989 contribution to this new literature of the West. 
The Jump-Off Creek is a contemporary Western novel about the Old West. Set in Eastern Oregon in the last decade of the nineteenth century, the novel features a woman homesteader as its main protagonist. Lydia Sanderson comes West to take up ranching in the Blue Mountains of Eastern Oregon, leaving behind an unhappy marriage and years of drudgery on a Pennsylvania farm. A childless widow, she comes West with certain "large fancies" (Gloss 114) and "grand obsessions" (Kolodny 3) concerning life in the West, not only to find herself confronted with neighbors who do not conform to her romantic notions of cowboys, cattle ranchers, and Indians, but also confronted with her own limitations as westering woman. In the course of the novel Lydia Sanderson is forced (along with the readers) to give up these "large fancies" in favor of a smaller and more accurate perspective of life in the West.

Gloss's novel The Jump-Off Creek, I would propose, is a deliberate and self-conscious rewriting of the story and history of the West. Gloss not only introduces a strong and independent heroine, but also uses the structural strategy of a doubly "divided narrative" which sheds light on a complex, interwoven, dialogical Western story. The Jump-Off Creek differs from a conventional genre Western. This is not a simple repetition of the homesteader plot of the Western in which a courageous individual, after struggling against an evil rancher or nature itself, overcomes her hardships. I would argue that Gloss operates within the frame, the fences of the traditional Western, taking familiar themes and characters and reversing them, thereby stretching the boundaries. In the following pages I will first look at how Gloss's choice of characters and plot surprises conventional notions about the West and its literature. Then, more 
importantly, I will analyze the relationship between public and private discourse in the novel and discuss how the blending of the public and the private discourse creates a multi-layered alternative Western story. Finally, I am particularly interested in "verbal and non-verbal activity"22 and what role language plays in this novel's vision of the West.

\section{Reversal on Character and Plot Level}

Gloss employs a subversive narrative strategy that affects all levels of her story. Gloss takes conventional notions about the West and Western literature and changes, even at times reverts them. The landscape which is most commonly associated with the West, for example, is the arid landscape of the American Southwest. Everybody who watches Western movies will remember the solitary grandeur of Monument Valley in Northern Arizona. Gloss's book, however, is set not in the flat desert landscape of the Southwest, but in the mountains of Eastern Oregon. Both landscapes are characterized by a lack of resources though. Gloss's strategy of reversals offers a problematized reading of the Old West and its literature and creates a new Western literature in which the old and the new are in dialogical relation to each other.

Gloss's choice to make Lydia Sanderson a single homesteader is significant in various ways. Gloss said in an unpublished interview that her initial incentive for writing The Jump-Off Creek was to write a genre Western that featured a strong female protagonist. The homesteader plot seemed the most natural choice, because she did not want to make Lydia 
Sanderson into a melodramatic cliché of a Western woman. She wanted to create a real, a "new" Western heroine in the Nietzschean sense without succumbing to the traditional melodramatic traits of conventional female heroines. 23 But by making her a "real" woman heroine, and not a cardboard copy, or a melodramatic cliché, Gloss's Western asks complex questions about the limitations of the genre Western. It is important that Gloss's woman protagonist is a homesteader, not only because the homesteader plot is one of the few genre Western plots, but more importantly because women homesteaders were a historical reality in the West (even though they have typically been left out of Western history). As Gloss said in an interview with Gregory Morris, "Women ranchers and homesteaders were much more common than is supposed--probably one in seven homestead claims was filed by a woman, and their rates of proving up were better than men's" (Gregory 132). The Homesteading Act of 1862 was the first law that allowed women to own a piece of land without depending on male representatives before the law. Although opinions concerning the significance of the Homesteading Act for women's Western history vary, it is only fair to say that this law enabled women to live independently. 24

Gloss' strategy of reversal is played out on the character level in various layers. First, Gloss complicates the concept of the Western woman pioneer by making Lydia a self-conscious pioneer. Second, Gloss's other characters also represent problematized readings of the typical Western heroes. Tim and Blue, the cowboys-gone-ranchers, are not the tough heroes of the traditional Western story, nor does Blue, the only Indian in this Western story, much resemble the stereotypical Indian. In fact, as Lydia has to 
ruefully admit to herself and the reader, "He [Blue] had rather less Indian about him than seemed" (186). The "bad guys" of this story are a handful of poor, run-down ranch-hands who have taken up the unheroic task of poisoning cattle to kill wolves in order to survive in an atypically inglorious West stricken with poverty and economic depression at the end of the nineteenth century.

Western critics Elizabeth Jameson and Rosalinda Mendez Gonzalez both draw attention to the claim that only privileged women of the middle or upper class could afford to move West, because moving West meant coming up with a considerable capital. Women of color and other minority groups could ill afford to come West and bring a year's provisions for survival on a homestead. In that respect, the Lydia Sanderson character belongs to a privileged class of women of the nineteenth century, but Gloss quickly reverses this notion. In a conversation with Blue Odell Lydia Sanderson confesses:

The truth is, Mr. Odell, when my husband died I sold every last thing of his just to get the money to come West. I suppose I was seeking the boundless possibilities that are said to live on the frontier." [my italics] (168)

Two points are important here: first, Lydia Sanderson is poor; she barely makes it. She wears her late husband's overcoat and gloves (it is mentioned several times throughout the novel) not for sentimental, but for practical reasons. Secondly, Lydia Sanderson reflects popular concepts of living on the frontier. Her romantic notions are soon reversed, though, as she finds herself working hard every day, cutting poles, trying to fix up her little house, and planting some vegetables. She realizes that the West 
offers her not "boundless possibilities" but rather a life restricted by a harsh climate, a short growing season, and the daily struggle to make ends meet. Soon, she finds her initial excitement fading: "The days became long, regulated, uniform" (132).

Lydia Sanderson not only has to overcome her own "foolish romanticism" (168) concerning the West, but also has to prove herself to her neighbors who have certain prejudices against women homesteaders, prejudices which the readers might share. When Tim Whiteaker first meets Lydia, she fits his image of traditional women homesteaders:

Once in Montana and a couple of times later in the Spokane country, he had known women who'd homesteaded alone. They had a steadfast look, or a doggedness, and now that he was watching for it, he could see it in this woman's face. (5)

Doris McAnally, one of the few women in this novel, confirms this typically male view of women homesteaders in the West by telling Lydia that she is only going to be a curiosity until the men have "made up their minds that you are bound to fail" (124).

As Elizabeth Jameson points out in her essay: "Women as workers, women as civilizers: True Womanhood in the American West" women in the West have often been associated with the stereotype of the "reluctant pioneer" (146). The cliché of the westering woman who is dragged out West by her husband, against her will, leaving behind the comforts of civilization, drawing rooms and women friends is turned on its head in Gloss's novel. 25 Lydia Sanderson comes to the West on her own account, to live her own life, "to stand under her own roof at last" (1). Neither does 
Lydia fall into the dichotomy of what Elizabeth Jameson calls the "polarized images of the genteel civilizer of the helpmate (or oppressed drudge)" (146). The only time Lydia was the oppressed drudge was when she was married to a lazy and abusive husband who made her do all the farm work. And whom might she civilize in this novel? The only "savages" that need to be civilized are the "bad guys," the wolvers who ride the grub line, and elude civilization. 26

\section{Structural Strategies}

What is significant in Gloss's portrayal of her main character Lydia Sanderson is that she allows her to reflect and question her ideas about life on the frontier. She provides her with a public as well as with a private voice, which serve different functions in the narrative. The public voice is the voice of the official narrative. The official narrative, I would argue, is the place where Lydia Sanderson admits her romantic ideas about her new life in the West. Here Gloss deconstructs the Old West and creates a "new" thing: Lydia tentatively stakes out her identity as the only single woman homesteader in relation to her neighbors. It is in her private voice, however, in her diary entries, where she reveals her utterly unsentimental sense of reality. Although she admits to Blue that she had high expectations of the "boundless possibilities" of the West, she writes in her diary after arriving at her new "home:"

[...] tho it is bad as I knew it would be, the stove rusted clear through, the roof rotted, the logs poorly fitted and 
mildewed, the yard where the Animals must stand all Mud and stones. I have not lost Heart, having done so in years past, and no false hopes this time. (35)

The diary functions as the narrative frame of Gloss's novel. Lydia's diary entries open and close the novel, marking a radical innovation in Western fiction. Gloss's novel is one of the few, if not the only Western novel, in which the readers have insight into the "diary side," the private side, of the characters. The diary serves a dual function in the novel. It is significant for what it tells the reader about Lydia Sanderson, and what it does not tell the reader, thereby also revealing something about how this nineteenth century woman homesteader interprets the world around her. In her diary Lydia Sanderson reflects on her daily deeds, in a short, straight-forward way, admonishing herself not to lose faith, explaining away weariness. The diary not only gives Lydia Sanderson an opportunity to reflect on her situation, on what is happening around her, but also provides her with the mental space to find her own place in the West. 27

The diary connects Molly Gloss' contemporary novel to an earlier tradition of women's writing in the West. The diary, the journal, the letter, these so-called "private writings" are among the few forms of written discourse that were available to women in nineteenth century Western America. 28 In Gloss's novel Lydia's diary entries serve as a powerful tool to bring together "official" and private writing, the urban and the rural voice, as Kerry Ahearn calls it in his essay "The Urban and the Rural in Oregon Literature." He states that Lydia Sanderson is placed "in a hardship landscape which is both an escape from her maledominated past and an opponent for her to prove herself against." 
"Significantly," he goes on, "the telling is a shared endeavor between the educated, authoritative urban voice we all recognize as normative in fiction and Lydia's rural voice, whose last words join in the themes of nature, hard farm work, a man, and the possibility of a community of equals" (37-38). Lydia's friendship with Evelyn Walker, for example, is described in the official narrative, and the readers learn something about the relationship between these two women by the way they speak, and even more importantly by the way their bodies speak. "Short, fierce embrace[s]" (82) repeatedly replace words that cannot describe the women's loneliness and the need for friendship. It is only through Lydia's diary entries however that we learn about the tricky relationship between Evelyn, Lydia, and Evelyn's husband and Lydia's careful maneuvering as single woman:

Mr. Walker came today w 2 loafs of bread frm his wife and took milk when I offered it tho nothing was said of a trade. I wished he could have brought Mrs Walker w him but know she should not come, as it is a long way \& steep and no wagon rd to bring her. She sent a sweet note of friendship which Mr Walker handed over w seeming mistrust, I do not know what he objects to, his wife finding a Friend or myself in particular. I smiled and presented myself as ladylike as liable to be with a hammer in my hands \& nails in my teeth! I know I will need to make Friend of him if I am to keep Mrs Walker for a Friend. (102)

Lydia's diary emphasizes the interdependency of people living in the solitary West. At the same time, Lydia's diary writing demonstrates what Patricia Nelson Limerick in her essay "Making the Most of Words. Verbal Activity and the American West," calls "westerners' (...) dependence on the written word as a device to hold things together when the process of 
expansion threatened to pull them apart (...) literacy as a mechanism of cultural (and personal) cohesion" (178). Lydia is at home in the public narrative as well as in the private narrative. This connectedness to two discourse communities becomes obvious when Lydia receives letters and parcels from relatives and friends. Tim witnesses that she belongs to an unfamiliar, that is female, discourse community that functions via letters, through the written word, from which he is initially excluded (138/139). Interestingly enough, it is when Lydia gets her mail, and Tim sees her connected to another discourse community, that their private conversation is most relaxed, friendly, and personal. It is where discourse communities intersect that true communication takes place.

The Jump-Off Creek is a doubly "divided narrative."29 Not only are there two complementing perspectives, Lydia's diary entries and the official narrative voice, but the narrative itself is divided into the men's story and the woman's story. In an interview with Gregory Morris, Gloss states her reason for writing two separate stories of the West:

It is illuminating to see people from more than one viewpoint, and that's some of what I was after. Also, I wanted to be writing a parallel men's story, Tim and Blue's story, which impinges on Lydia's story only at a few places. The men's story and the woman's define each other, I think, in ways that wouldn't have been possible if I'd stuck only to one. (134)

I am interested in how the men's and the woman's stories differ thematically, in their treatment of language, and what the intersections signify in this story of the Old West. I would argue, along with Gregory Morris, that it is the places where the men's and the women's story intersect, that communication and a learning process take place. $30 \mathrm{I}$ 
would further argue that the dialogue between the men's and the woman's narratives, the crossing over boundaries, is what makes this novel so innovative in its approach to the Old West.

The men's story and the woman's story tell two different tales, but intersect at certain important moments. Whereas the men's story is more traditionally Western, featuring an escalating conflict that inevitably leads to death, the woman's story concentrates more on community building and peaceful negotiations among neighbors. But this simple opposition is not quite appropriate if one considers that the men's story also inhabits men like Tim Whiteaker, who cooks for a logging camp in order to earn some extra money--he is a better cook than Lydia, as a matter of fact--and Blue, who is quite the opposite of the savage Indian. Tim Whiteaker, although he proposes to Lydia and thereby contributes to the romance plot, is far from being the romantic Western hero, if only because he is excruciatingly aware of his own shortcomings. The woman's story features a woman like Lydia who does not only do men's work like cattle ranching, but who at the same time dreads to be asked to help Evelyn Walker deliver her baby. The women's and men's stories cross over into each other's territory. The fences between the conventional gender roles are lowered, deconstructed if you will. In this dialogical space, Tim and Blue can ask Lydia for help, and Lydia can work as a cattle rancher and surgeon. Cooperation among men might happen in conventional Western fiction, but two men collaborating with one woman is a "new thing". Nevertheless, when one compares an incident that takes place both in the men's and the woman's story, it becomes obvious that conflicts are solved differently. When a marauding grizzly enters Lydia's property, she makes 
it leave by yelling at it. She follows its footsteps, but when she sees that the bear has left her property, she doesn't pursue it any further. She is merely interested in protecting herself and her livestock (66-67). Tim Whiteaker and Blue's reaction to the same bear, on the other hand, is quite different. They decide to follow it. Hunting the bear down does not merely mean protecting their livestock, but takes on an altogether different perspective. Tim's hunting instinct is aroused, and he is thrilled by the sense of a possibly dangerous adventure: "When he looked at the prints, a prickly excitement crawled up the back of his neck and sang in his scalp" (86). But the adventure with the bear proves to be disastrous. As a result, Blue gets badly injured; the bear and one of the horses die.

The confrontation with the bear that (almost) inevitably leads to death anticipates the outcome of the men's story. Tim and Blue, the two cowhands turned ranchers get into a conflict with three cowboys turned bad. The relationship between these two rival parties is marked by a sense of impending danger and unspoken threat from the very beginning of the story. (Rather than speaking directly to each other, they move in rhetorical circles, alluding, but never stating their affairs directly.) Once the two rival parties confront each other, it is only a matter of time until the smoldering conflict escalates. Harley Osgood, Gloss's Western anti-villain, is most aggressive. He substitutes violence for verbal communication. He kicks Tim in the face when Tim asks for help after Blue has been injured by the bear. It is Harley who initiates the traditional Western shoot-out plot in the end. He kills Blue, but also gets killed himself. The equation of good versus evil does not fit. Harley presents an interesting reversal of the Western villain. By making him a puberty-ridden problem child, Gloss 
makes a profound statement about the maturity level of the Western hero/villain. Harley feels insecure and inadequate. He can act violently, or, when prohibited from violence by the presence of a woman, become verbally abusive. When Lydia coolly rejects his request to spend the night at her cabin, but politely offers him some milk, he can only vent his frustration in swear words:

"Horsefaced old bitch," he said running the words together loud and wet. "Stupid old woman." It was a longstanding comfort. He had used to go out in the corn or down along the rock road below the house when he was twelve years old, fourteen, and swear out loud at his mother. Old bitch cunt slut. Swearing until he had quit crying. $(48 / 49)$

What is interesting here is Harley's relationship towards language. He is described as a taciturn young man, who "generally (...) spoke as little as he could get by with. (...) But if he was provoked, or felt on the least wobbly ground that way, he found he could get his look up straight and the words that would come out then would be straight too, and quick" (29). $31 \mathrm{His}$ only language is a burst of swearwords, otherwise he keeps quiet. This non-communication is linked to a more overall thematic emphasis in the men's story. Competition and the survival of the individual are more important than interdependence and communication. When Harley's group, for example--the one group which is hit hardest by the economic depression of the last decade of the nineteenth century--finds that its year's work amounts to nothing in money, one of them just takes off to fight for himself. The shaky solidarity within the group breaks down under economic pressure. Everybody has to make it on his own in the West of masculine individualism. 
The Woman's story on the other hand has more to do with community-making than with violence and competition. Lydia, Doris, and Evelyn have a number of scenes in the kitchen, where they exchange their experiences and ideas and so establish friendly relationships with each other. The women's story offers a valuable alternative to Western literature in that it stresses community over individualism. Although each individual group of homesteaders lives alone, it is ultimately the community that keeps people alive and sane. Even though people live far away from each other, they make a great effort to cross the distance to see and to help each other out. Lydia, the central character of the woman's story, is dependent on trading milk against cash or other goods with her neighbors. She first tries to sell her goods to Mike Walker, her new friend Evelyn's husband, but later has the opportunity to sell her milk to Tim Whiteaker's cook camp on a more regular basis. It is important to note that Tim Whiteaker is the one who offers to buy her milk which demonstrates that where the men's and the woman's story intersect, a learning process is possible. Tim and Lydia share goods with each other, he leaves pies for her on her doorstep. Tim and Blue help her with the cattle branding. Lydia sews up Blue's bear wounds, and nurses their dying dog. What is stressed here is the protagonists' sense of connectedness, of depending and relying on each other for the daily struggle to survive in a West that is quickly changing from a predominantly cattle ranching West, to a more domesticated and fenced-in West. 


\section{Language in the West}

On the Western frontier men and women each have their own way of talking. Whereas the women share their intimate experiences with each other, discussing personal topics such as menstruation, childbirth, and their struggle with loneliness, the men talk about the economic depression or how the cattle business is changing. When women talk to men, there is a "general softening of voices, a falling off of talk" (143). At the same time, women and men share a similar attitude towards verbal communication. The characters are not free of social conventions, in this supposedly free West. On the contrary, the characters are as fenced in their manners and discourse conventions as their goats and cattle are in real fences. Lydia's fence-like smile amply demonstrates her own restrictions. The West in Gloss's vision is not a place of "boundless possibilities" where individual freedom is all that counts. Rather, it is a place well staked out by fences and borders. The fence metaphor weaves in and out of the different narrative strands, connecting the different stories and characters. Gloss's characters are not only frequently shown to cross over, let down and raise fences around their properties, but they are also depicted as staking out their mental and psychological boundaries on a verbal and non-verbal level. In this West, the staking out of mental spaces is paralleled by a sense of the closing, that is the fencing in, of the frontier. Whereas the mental spaces are slowly opened up, through the efforts at communication, the geographical boundaries are raised.

Communication means crossing boundaries, crossing the internal and external fences, opening up, becoming vulnerable. Verbal language and 
nonverbal gestures are the tools for engaging in communication with others. But silence also makes one vulnerable to misinterpretation. Lydia, for example, is always afraid to be misinterpreted. She is careful how she comes across her fences. She uses her fence-like smile as de-fence. Her caution is mirrored in the careful way she approaches other people's space. When Lydia approaches Tim Whiteaker for the first time, their nonverbal and verbal communication is a careful staking out of grounds. Similarly, Lydia's fences are up when she meets Evelyn for the first time.

She pulled up the saddle mule when she was still a little way from Tim.

"How do you do," she said, gravely polite, and in a moment, smiling in a flat way, "I smelled your campfire smoke." [my italics] (3)

She came slowly on the black mule lately named Rollin. It seemed to take a long while to get across the grass with the woman standing there watching her come, and then hard to tell at what point she ought to call out a hello, or stop the mule and wait to be asked in. She felt a little rigid smile fixing itself on her face." [my italics] (75)

It does not matter whether Lydia encounters a man or a woman, she feels awkward and self-conscious. In both scenes Lydia is aware that she is entering another person's space, and cautious to behave appropriately. Both encounters are accompanied by the description of body language. In both cases Lydia finds herself smiling, not joyfully, but "flatly" or "rigidly." The gesture of the smile has not only become a token of good will, an attempt at communication, but also a de-fence mechanism. Whether and how this gesture ultimately works is unclear. The language that is used to describe Lydia's gesture is the language of military actions: "She tightened 
her mouth, raising a familiar buttress against misery"(21). The characters in this novel seem to be tentatively trying out words and gestures, putting them to use without really knowing how to use them. Gloss says in an unpublished interview that the care with communication results more from the fact that these characters live such solitary lives rather than from an incapability of expressing themselves. She points out that people living in isolated places in the West often do not have the opportunity to talk to anybody for quite some time, and that therefore their ability to communicate with other people through words becomes rusty. Male and female characters are similarly afflicted with this word-dis-ease. Taciturnity then is not a question of being powerful, as Jane Tompkins's influential study West of Everything: The Inner Life of Westerns suggests, but rather due to the living situation in the West. When Lydia talks to her new women friends, Evelyn Walker and Doris McAnally, for example, she finds herself in conflict of telling too little or of revealing too much: "Her face felt red and stiff. She had not ever told that much to anyone" (82). Language is not entirely in her command. Tim, too, is struggling to find the right words and the right discourse conventions. According to Gloss, verbal encounter between the characters is often preceded by a physical disruption of personal space, by a crossing of boundaries that puts one person at a disadvantage. When Tim Whiteaker enters Lydia's space and starts cutting trees on her property in an attempt to help her, or as she interprets it "to repay an act of neighborly kindness" (104) for stitching up Blue's bear wounds, Tim literally senses her tenseness: "Her look made him want to stand back, as if she had on a coat of long barbed spines" (104). The nonverbal gesture of resistance is cloaked into a verbal invitation to 
come and have some coffee inside her house, her intimate space of confinement. Conversation goes slowly and awkwardly. When she does conversational work, referring to the weather as a safe topic of conversation, he is lost as to what the conversational conventions are: “He nodded again. 'I guess it has.' Then, pulling his head down, plunging in, 'I am from Nebraska myself, but that was a long time ago.' She gave him a startled look. Immediately, he knew he had bungled it stupidly" (105). Tim plunges in the unfamiliar terrain of polite conversation and is unsuccessful. Equally out of the blue comes his proposal of marriage:

He sat looking into his coffee.

"I expect you wouldn't want to try marrying again," he said in a slow way, and feeling the heat come up slowly in his face. She looked at him. He kept his eyes on the cup of coffee held carefully level on one knee.

"I don't know if we could get along," he said. He looked at her quickly and then away. For a moment the only clear thing he felt and recognized in himself was dread.

"I don't suppose we could," she said after a silence. (108)

Again, Tim throws himself across the fence without a word of warning, but this time carefully constructs his retreat. He phrases his proposal of marriage in a rhetorical mode that already implies a negative answer. In this scene communication between Lydia and Tim happens in between the lines, in the silences, the gestures, the averted gazes. The marriage proposal is a disaster, and their carefully built up relationship is threatened for a while after this event. Tim Whiteaker never enters her house again.

Body language and non-verbal communication methods seem to be easier to read than actual words. Tim Whiteaker, for example, ducks his chin like a horse that wants to get rid of the bothersome bridle. Lydia 
Sanderson, as already mentioned, fixes rigid smiles on her face, that do not reach her eyes in order to disguise her discomfort. Rather than reflecting certain power relations, this speechlessness reflects concern with the spoken word. The speechlessness, or the cautious use of the spoken word transgresses gender boundaries. The women as well as the men characters try to juggle their expressions in language. Often enough, "short, fierce embraces" (82) among the women take the place of words. Oddly enough, the only person who is socially adept and completely at ease is Jim Stalling, a man who immediately asks Lydia whether she wants to be his third wife and the mother to his eleven children (126). Communication in this novel means a careful negotiation between language and action, between speech and silence, between verbal and nonverbal expressions.

Gloss's West is aware of its traditions. The Jump-Off Creek does not only respond to the underlying assumptions of what a Western novel should be like by reversing conventional themes, or at least expanding the agents in this Western drama, but also by referring to historical women pioneers who function as Lydia's foremothers in spirit. Gloss's choice of placing her contemporary Western novel into a literary and historical context is significant in that it takes seriously the challenge of postmodern theories that question the enterprise of rewriting history as overarching history. By placing her novel into a female tradition of Western writing, Gloss engages a feminist poetics. At the same time, her novel is selfconsciously intertextual. When Lydia in the end rejoices that her river was named because other women pioneers came through her territory, she claims kinship with them. She writes in her diary: 
He said that the Jump-Off Creek was named due to the Whitman party camping along it in 1837 on their way to starting the mission at Waiilatpu, it was the "jump-off point" for crossing the Summit of the Blue Mts \& down onto the Walla Walla plains. I was rather foolishly happy when I heard it, as Narcissa Whitman \& Eliza Spalding in that Party were the first White Women to cross the Continent, and I believe I felt some kinship $w$ them. (186)

Lydia Sanderson is then not only a contemporary re-vision of a nineteenth century homesteader in Eastern Oregon, but within this historical framework Lydia is aware of her own historicity. She is able to acknowledge that other pioneer women have named her river as "jumpoff point" for their Western lives. Gloss's novel, then, is nothing but another jump-off point, a different place of departure, for the next generation for Western women writers to come, because it bridges the gap between the Western past and present. The Jump-Off Creek is a contemporary woman's critical reading and creative re-writing of the Old West.

Gloss's novel The Jump-off Creek gives voice to more than one story in her story of the woman homesteader Lydia Sanderson. Her story is an intricate network of narrative strands that form knots and strong strands together. What is significant about this doubly divided narrative is that it provides Gloss with several intersecting perspectives, the men's story and the woman's story, the official urban voice, and Lydia's private voice. The intersections between the men's and the woman's story provide spaces of interaction. The novel ends with Lydia's diary entry in which she reflects on her conversation with Tim Whiteaker: "We had a talk about putting up Hay, Mr. Whitaker more disposed to it that before time. When I said I had 
made Hay, he said he would learn it from me if I would teach him, and I said I would" (186). Interestingly enough, it is the "modernization" of the West in the 1890s which forces cooperation--haying and fencing replace the older competitive hunter/rancher ethic. The idiomatic expression of "making hay" which can be read either as getting romantically involved or as using the available opportunities, is especially fitting. The novel ends on an affirmative tone, a notion of interdependence and a language that cuts across the boundaries of gender and territorial conventions. 


\section{CHAPTER III}

A MULTIVOCAL CANON IN THE (UN)HARMONIOUS OLD WEST:

KAREN FOWLER'S SARAH CANARY

What we say occupies a very thin surface, like skin over a body of water. Beneath this, through the water itself, is what we see, sometimes clearly if the water is calm, sometimes vaguely if the water is troubled, and we imagine this vision to be the truth, clear or vague. But beneath this is yet another level. This is the level of what is and this level has nothing to do with what we say or what we see.

Fowler, Sarah Canary, 280

"People speaking a foreign tongue often appear more logical and intelligent than those who can be actually understood."

Fowler, Sarah Canary, 4

In the last five years or so mainstream TV has featured numerous shows and movies that portray the experience of ethnic minorities and women in the historical American West. With the celebration of the Columbus year in 1992, not only the New Native Americans, but also Mexican, African-American, and Asian immigrants figure as protagonists in this "revisionist" approach to Western American history. All these diverse stories tell the same traditional old tale of upright citizens fighting against gun slinging outlaws, independent cowboys fighting against corporate ranch managers. The plot of the Western story of John Wayne and pals has not changed, even if the skin color of its protagonists has. This revisionist approach of the popular media is superficial, lacks critical depth, and a necessary self-consciousness in the treatment of its own terms. To merely replace Anglo-American characters with ethnic protagonists is 
to ignore the complex history of ethnic minorities in the dominant AngloAmerican culture of the American West. Furthermore, it is to ignore the specificity of each individual ethnic history in an ethnically heterogeneous West. 32

What contemporary film has not done, contemporary fiction has. In the following pages I will discuss the ways in which Karen Fowler's 1991 novel, Sarah Canary, unravels a monolithic, static, and predominantly male Anglo-American version of the historical American West by radically altering the cast of the Western story. By placing the question of perception at the center of her novel, Fowler destabilizes the idea of a "true" version of the historical West. Sarah Canary does not only tell one story of the West, but numerous stories are spun, which refer to, respond to, and interact with each other. Ultimately then, Fowler's novel calls into question the notion of rewriting Western history and literature.

\section{Rethinking Concepts}

As in Gloss's novel The Jump-Off Creek, readers of Fowler's novel Sarah Canary have to rethink their concepts of Western fiction as well as their notions of Western history. We are not dealing with the shoot-outplot of the brave, traditional Western cowboy-hero such as Owen Wister's Virginian or Jack Shaefer's Shane, both classic examples of the Western genre; rather, we are dealing with the romantic, at times ludicrous, quest plot of a Chinese anti-hero. In Fowler's novel the protagonists are the outcasts, the throwaways of Western society. They are a handful of loners 
and losers. 33 The scene is Washington territory in 1873. The action of the novel begins when a mysterious white woman, who is uncommonly noisy and uncommonly ugly, suddenly and miraculously appears in the camp of the Chinese rail workers. Chin, the miserably homesick and powerless Chinese anti-hero, initially mistakes her for a ghostlover sent to him from the immortals to deliver him from a tedious fate and a life constantly endangered by anti-Chinese racism. 34 When he attempts to return her to the white world, Chin enters a series of adventures and mishaps. In the course of the novel, Chin spends a night in jail, hangs the American Indian Tom, almost drowns in his pursuit of the mysterious woman, falls in love with the outspoken suffragist Adelaide Dixon, and finally returns to China, thus leaving behind a country that was not so golden after all. In his chase after the mysterious woman--later called Sarah Canary--Chin is joined by three other characters: B.J., an escapee from the Insane Asylum at Steilacoom, Adelaide Dixon, a suffragist who tours the American West lecturing on female sexuality, and the villain Harold, who thinks he is immortal just because he did not die during the Civil War. As these various characters puzzle over the identity and purpose of the mysterious woman Sarah Canary --named after the infant terrible of the Old West, Calamity Jane, whose full name was Martha Jane Canary--they come to question their own perception of reality as well as their relationship towards the other characters. 


\section{Discourse Layers}

Fowler employs various narrative strategies to unsettle the notion of a stable story of the Old West. The novel is made up of multiple discourse layers that intersect at various points in the narrative, so that they are commenting and responding to each other. These discourse layers not only offer numerous narrative perspectives, thereby opening up the novel's overall narrative to more than one interpretation, but they also weave in and out of the chapters and pre-chapters as well. This method itself encourages alternative ways of looking at one discourse.

One of the main discourse layers concentrates on the Chinese experience in the American West. Chin's story constantly negotiates his Chinese philosophy of life with Western American attitudes and conventions. Fluent in more than two languages, Chin has to serve as interpreter between his Chinese working colleagues and the Western American white world--a task nobody seems to thank him for. His Chinese colleagues, especially his uncle, think that adapting to the English language equals a selling out, a giving up of his Chinese-ness. The interpreter is always suspect. The white world, the "white demons," as the Anglo-Americans are called by the Chinese, discriminate against the Chinese "underdogs." Chin's experience in the "Golden Mountains," then, is characterized by a feeling of not belonging. He does not quite belong to his Chinese countrymen, and certainly does not belong to the Anglo-American Westerners. Chin feels lost and alienated. Although he has the outsider's keen eye, and is able to learn a lot about the American culture by looking closely at the English language, he is still the outsider, the exotic Other, the 
Chinese underdog. 35 His narrative is set against the narrative of the prechapters, which are made up of odd bits of information concerning the political status quo in China, and the acts of discrimination against the Chinese in America.

Another discourse layer focuses on white woman's position in the American West. It does not only tell Adelaide Dixon's story of success and self-doubt as female suffragist lecturer in the American West, but also connects her struggle to news from other outrageously daring historical women, such as Victoria Woodhull, Elizabeth Cady Stanton, and Ann Eliza Young, all advocating women's causes in nineteenth century America. The discourse around the position of white women in the American West also takes place on more than one level. We find it in the story of Adelaide Dixon as well as in the pre-chapters in which Fowler interrupts the narrative to give seemingly random pieces of historical data on the woman question, or the situation of Native Americans, or strange apparitions, or the political climate in China. These pre-chapters are an important structural device, because they establish connections between the Western past and present, between the historical discourse of nineteenth century America, and the narrative discourse of the novel. Reading these pre-chapters, the reader is often reminded of the process of flipping through a newspaper, and picking up curious information, ranging from political analyses to gossip. It is an interesting technique, resembling the postmodern pastiche, in which several literary forms are assembled to demonstrate the arbitrariness of claims of literacy. The last pre-chapter, significantly connects nineteenth century America and China to twentieth century events in America and China: the massacre of 
Tiananmen Square in 1989, President Reagan's comments on Native Americans, scientific experiments with frogs and a minister's sex scandal. The novel ends with quotes from newspapers. These pre-chapters do not only connect, but also disconnect, deconstruct the concept of a coherent historical narrative. They point to a multi-faceted, multi-layered Western discourse in which the Native American perspective is expressed through Chief Seattle's speech on the condition of the Native Americans in postsettlement America as well as through a Native American folk-tale of love and betrayal. The Indian blanket swaying in the wind tells a story about Coyote's daughter marrying Raven against her father's will and Coyote's subsequent revenge.

\section{De-Sanitizing_Sanity}

The one discourse that affects all characters, all other discourses, and ultimately the question of re-writing the Old West, revolves around the question of what the characters, and therefore also the readers, perceive as sanity. Both the figures of Sarah Canary and B.J. are central to this discourse. As with the other discourse layers, the question of sanity is not only dealt with on the narrative level of the plot, but also reflected on in the pre-chapters. The pre-chapter to chapter three that takes place in the Steilacoom Insane Asylum, gives a brief introduction to common knowledge and beliefs concerning sanity. It sketches the connection between saintliness and sanity, claiming that 
Sanity is a delicate concept, lunacy only slightly less so. Over the last few centuries, more and more of those phenomena once believed to belong to God have been assigned to the authority of the psychoanalyst instead. Some of the saints can be diagnosed in retrospect as epileptics. (35)

Insanity, psychosis, and hysteria were mostly associated with women in the nineteenth century. Freud and earlier psychoanalysts deal especially with female subjects. It was believed that women are more prone to madness because their bodies were less stable, less under control. Science had it that women are very much at the mercy of their biological cycle. Throughout recorded history, men have developed elaborate theories which align women with madness and insanity, and of course, the idea that they are more prone to suffer from hysteria. These conventional psychological theories are reflected in Fowler's episodes that take place in the Insane Asylum in Steilacoom, where the inmate B.J.--himself suffering from a disturbed sense of perception--and his psychiatrist Dr. Carr, discuss the condition of women:

the menstrual cycle, which represented the disappointment of the maternal instinct, could occasion a gross perversion in which the natural feminine desire to procreate became instead a desire to kill. $(41-42)$

What is interesting in Fowler's novel is that the common stereotypes against women and madness are partly voiced by B.J., who is himself an inmate of the Insane Asylum. When Sarah Canary, so named by another inmate because she sings so beautifully, is brought to the Asylum, the 
common verdict is that she went mad because she was attacked by Chin, the Chinaman. For a woman to outlive such a supposed threat to her body and mind would have been unforgivable in Victorian America, and madness is the only "decent" alternative to death. Sanity and morality are concepts that are linked in nineteenth century thought. The science of physiognomy which determines inner character traits from outward appearance, introduced by Swiss scientist Lavater, is also applied to early psychology as can be seen by Dr. Carr's evaluation of Sarah Canary: "the woman in black had the classical facial features of the criminally insane (...) Thick black hair, gray eyes, diastema of the teeth with exceptionally large canines, a repulsive, virile air, and big, sensual lips" (41). Sarah Canary's "condition" is at once attributed to her moral standard of decency, and her innate criminal instincts. But, both sides categorize her as mad. The intriguing phenomenon is that Sarah Canary poses interpretive problems for the people around her. She clearly does not behave like a "normal" person. As Fowler says, "sanity is a delicate concept." By calling it a concept, Fowler opens up the term that has for the longest time just stood by itself. By contextualizing it historically, Fowler calls into question the stabilizing truth of differentiating between sanity and insanity.

Sarah Canary, the crazy woman, is the central disruptive force in the novel, and central to the question of sanity and madness. Her strange behavior provokes other characters into thinking about their own concepts of sanity, madness, and civilization. She is less a character and more a catalyst to the novel's action. She engages the other characters in dialogue, not with her, but inwardly with themselves and each other about her; they wonder what her motivation and purpose is. The characters are also in 
dialogue about how the characters see themselves in relation to her, and the rest of their world. The characters' perception of Sarah Canary and themselves is not stable but in flux. Sarah Canary is the crazy woman-Gilbert and Gubar's "madwoman in the attic" let loose, the ultimate frontier in Leslie Fiedler's terms. 36 She is everything to everybody. She is immortal beloved/ghostlover to Chin, she is murderess and victim of patriarchal society to Adelaide Dixon, she is embodiment of female sexuality/savage freak to Harold, and she is madwoman to madman B.J. She is like the Western American frontier: elusive, undefinable, and finally a product of the readers' imagination.

It is because of her that Chin meets and hangs the American Indian Tom. It is because of her that Chin and Adelaide meet and engage in dialogue. It is because of her that Chin and B.J. become friends and exchange stories of the Western world for stories of the Eastern world. When she disappears in the end, the characters as well as the readers ask themselves whether she was really there in the first place. Maybe she is what Chin describes at the end:

Sometimes one of the greatest dreamers passes among us. She is like a sleepwalker, passing through without purpose, without malice or mercy. Beautiful and terrible things happen around her. We discern symmetries, repetitions, and think we are seeing the pattern of our lives. But the pattern is in the seeing, not in the dream. (287)

\section{Language and Perception}

Her speech is "lunatic." She talks incessantly without making any sense at all, but Chin, and the other characters as well, attempt to interpret her all 
the same. It is not altogether clear whether her speech is made up of "syllables of joy" (12) or "frenzied, high-pitched gibberish" (8). Her speech is made up of "strange (...) clicks and bangs" (7). Chin, who grew up around foreign languages, and who is fluent in more than one, is at a loss when he is suddenly confronted with the nonsensical babbling of the mysterious woman in black. Through her Chin learns that none of his languages, not even his body language and facial expressions, have the desired effect. She does not do what she is asked to do. She answers him with a "steady and joyful stream of nonsense" (8). Chin is questioning his own perception of what he learns and so helps us to realize how arbitrary the conventions of language and communication are: who is to say that what we perceive others to say is really what they say, let alone what they mean when they say it. When the woman gestures to him to come closer, Chin is not only uncertain of what to do, but also uncertain about whether or not the woman gestured to him in the first place:

The woman in the forest gestured for Chin to come closer. Chin asked himself what could be gained by any intercourse with a white woman who had hair above her lip and also a nose that was long even by white standards (...) It was not at all clear that the woman had been gesturing to him, anyway. (5)

The reader is doubly confused here: obviously the relation between sender and receiver is questioned, but whose interpretation is it? Who interprets the woman's speech and actions? It seems to be Chin, but when Chin doubts his own perception, is that the dominant narrative voice? On one level the woman in black seems to respond to Chin's attempts at communication, only her reactions do not correspond to the meaning of his words. When he tells her to shut up because he is afraid that the 
Indians might hear them, she keeps talking (16). When he tells her to go away, she stays. The gap between what he says and means and what she hears him say and mean is deep. On another level, the narrative voice interprets her language, her form of communication as either joyful or sad. Even if there is no meaning readily available, there is at least a mood, some very basic form of communication. But again, it only works one way: Sarah Canary's reactions to the people around her seems to say that she cannot make sense of their attempts at communication. The Sarah Canary figure, then, is a mirror for the other characters in which they see distorted reflections of themselves. What they say and what they mean does not make sense. Sarah Canary is the force which questions other people's perception of the world.

Fowler quotes Camille Flammaron at the beginning of her novel: "You only comprehend things which you perceive." But the question seems more complex yet. What if what you perceive is not what is? Or, what if your perception of one thing undergoes constant changes? Chin, for example, perceives Sarah Canary in widely differing terms. His interpretation of her undergoes constant changes, from ghostlover to opium addict, to coquette, to crazy old woman. When he first sees her, he thinks that she is the ugliest woman he has ever seen (5), but soon he finds something beautiful in her:

She smiled at him and her nose hooked toward her mouth. She hummed her answer. Her skin--he noticed this suddenly--was poreless and polished. It shone like Four Flowers porcelain. It was beautiful. He was a little bit frightened. Why was he seeing this? Why hadn't he seen it before? Why was he seeing it now? (13) 
In this novel perception itself is questioned. And if perception is questioned, what does that mean in terms of rewriting the historical West? Does that mean that we have to be careful whose perception we trust? Or does that mean that the truths of the Old West are relative, depending on how you perceive them? Or both? If everything is a matter of interpretation and re-evaluating the seeming importance of interpretation, then the enterprise of rewriting the historical West becomes increasingly complex. If Chin has to constantly re-evaluate his own perception of the world around him, then surely we as readers need to do the same thing. Fowler invites readers' critical participation in the telling of the numerous Western stories by drawing our attention to the changing nature of our perception of this Western novel.

\section{The Act of Storytelling}

In Sarah Canary, story-telling emerges as the basic story. It plays with words, it turns meaning on its head, and ultimately asks the readers to question their perception of what is told in the stories within the story. Do any of the stories count more than others? If all we have in history is a collection, an assembly, of stories different from the traditional archives, then the question of which stories dominate over others is less relevant than why some stories get heard over others. In Sarah Canary stories create new stories, stories talk to each other, refer back to earlier stories. For example, when Chin and B.J., his new traveling companion, set out after Sarah Canary, they make sense'of the world by telling each other 
stories. Chin starts with a Chinese folktale, and B.J. quickly translates the foreign story into one with which he is more familiar. A Chinese folktale then becomes an European, or now rather an American, fairy tale.

Story telling and language are intimately connected. If one cannot understand the language, the listening is harder, but not necessarily impossibly difficult. As Fowler says early on in her novel: "People speaking a foreign tongue often appear more logical and intelligent than those who can be actually understood" (4). It is not so much that every word connects to a certain meaningful concept, but rather that language is completely arbitrary. What follows is that even if one does not speak a certain language, that does not necessarily mean that the stories are not there. It is just a matter of not being versatile, not being multi-lingual, enough. To well understand the stories of the Old West, one must perhaps be like a Grimm's fairy tale hero: a multilingual trickster who can speak and listen in tongues. Tom, the American Indian, states it quite clearly when he says: "The earth talks to us, but we don't speak its language. Why should it not mean something just because you don't understand?" (22). Language encompasses more than just human language, (and even in human language there are an indefinite number of other tongues) but also the language of material things, and elements, the earth, the wind, and the water. Communication happens on more than just the verbal level. There are sign languages, material languages. There are an indefinable number of ways to communicate and an indefinite number of stories that need to be listened to.

B.J. provides a good example of a character who understands the language of material things better than the linguistic codes of the English 
language. Even though he is really unsure how to communicate verbally, and prefers tag questions to all other forms of sentence types because they give away the answers in the question, he is able to understand the language of keys and knives. Or maybe he is not able to understand keys and knives, but interprets their materiality in terms of communication codes, signs--again language of some sort. The objects around B.J. talk to him. For example, the kitchen knife tells B.J. to cut Chin's braid off:

There was a code to the flashing light. The knife wanted many things. The knife wanted the winter turnips and the last of last year's potatoes and the side of beef hanging in the pantry. The knife wanted the China man's braid. Lay it across the table and cut it off. Three blind mice. Three blind mice. The knife sang insinuatingly. (47)

Chin, the multilingual protagonist, brings the outsider's keen eye and ear to American culture. He has the advantage of looking and listening consciously and reflecting on what other Anglo-Americans would not even notice but accept as daily language. He questions what idiomatic phrases mean, and interprets them as reflection of the dominant AngloAmerican culture: the English expressions "I am all ears" or "You are all heart" he understands as "typical Caucasian overstatement" (236), as typical Caucasian optimism. Language determines and reflects culture. Language does not exist in a vacuum, it changes, grows, develops, contracts and expands. It indeed informs the way we think and feel about the world around us. Words matter, words change. 37 But Chin is afraid to talk. He is afraid that speech will render him visible to others. His life is in constant danger, because the Anglo-Americans, or as they are called by the Chinese, the "white demons" threaten to kill and abuse the Chinese laborers. Times 
are hard in the American West. The cheap Chinese labor force, that was initially supposed to replace the Negro slaves on Southern plantations, is now used as the ultimate scapegoat, the embodiment of the exotic, the Other, that is threatening the dominant culture of America:

The economy was depressed and so were the white men. The American Congress had just announced its intention, given the alternatives, to depend in the future on Nordic fiber. Nordic fiber had settled the Midwest. Nordic fiber could win the West as well. The Chinese, according to this thinking, while well suited to railway work, were not otherwise needed. They had no families and were absolutely indifferent to human suffering; (...) They had been massacred in Los Angeles's Nigger Alley and in Martinez (...) Chin understood quite well, his uncle did, too, though he didn't always admit it, that it was best to be invisible and, when that could not be achieved, then quiet, at least. [my italics] (7)

Fear is the basis for Chin's silence, not the wish to stay in power. Jane Tompkins's claims in her study of the Western's language in West of Everything: The Inner Life of Westerns that:

Not speaking demonstrates control not only over feelings but over one's physical boundaries as well. The male, by remaining "hermetic," "closed up," maintains the integrity of the boundary that divides him from the world (...) To speak is literally to open the body to penetration by opening an orifice (...) Finally it suggests a certain incompleteness, a need to be in relation. Speech relates the person who is speaking to other people. (56)

Speech means presence, visibility, and ultimately vulnerability. If you are not there, nobody can hurt you. If you are there, and make your physical presence known to others through language, you can be hurt. 
While it is within the power of language to become visible and present, there is also the possibility of not becoming visible and present through language. 38 For example, there is an interesting difference between B.J. and Chin: whereas Chin dares not speak for fear of becoming present, visible, and vulnerable, B.J. needs physical and material proof of his existence. Language for him does not confirm his existence, but the mark on the kitchen wall confirms his physical presence, which may be part of a different concept of language altogether. Language, the cognitive act of expressing yourself, means nothing to him. B.J. transforms the Cartesian "I speak; therefore I am" into "I am; therefore I am."

Ironically, all this conversation of what is the meaning and use of language that goes on in the various discourse layers is set against a background of the country of "boundless possibilities" (Gloss). What does it mean not to be able to express yourself freely, especially in a country that prides itself on its right of freedom of expression? There are really two conversations going on at the same time: on the one hand, the West has always been associated with the ultimate freedom of the individual, with the fulfillment of dreams and hopes that had no space to grow and develop in the stuffy and overly cultured East of the United States. At the same time, the West has always stood for the opposite of the East. Whereas the polite, feminine conversation of the drawing room dominated the East, the West was seen as the place where words were less important than manly deeds. Fowler's novel is responding to these contrary conversations: on the one hand, her male protagonists show a desire to speak, to tell stories and thereby to make sense of the world, but they are helpless, not at all free to say and do what they like. On the other hand, the 
female protagonists disrupt all polite conventions of conversation, and either talk nonsense incessantly, or talk outside the sanctuary of the drawing room and enter the male space of the West.

The roles between men and women are turned upside down in this Western novel. It is the women who are powerfully eloquent, whereas the men struggle with expressing themselves. The silent powerful male hero is paradigmatic of the classical Western, but here silence takes on a different connotation. Chin craves to express his homesickness and loneliness, but he is in a double bind. English is a second language for him and he cannot express all the subtle variations of tone and pitch in English anyway. He longs to talk, to speak freely, but in English everything sounds flat: "To Chin, who was used to the six tones of Cantonese, all English was expressionless" (24). He hits the woman in black because he is afraid that her noise, her constant chatter will attract Indians, of whom he is as afraid as of the white Americans. He hits her to silence her, which is in accordance with the traditional Western hero's behavior who prefers actions to words. In this case, Jane Tompkins's theoretical paradigm of the silent and closed-up male, who is incapable of speech because that would make him vulnerable, is taken literally. Chin is truly afraid that the woman's talking might get him into some physical danger. Actions end words. Or rather, body language dominates over verbal communication. Almost immediately he feels sorry and confides in the crazy woman, another Caspar Hauser case perhaps, someone who can "hear without understanding, and (...) see without perceiving" (244):

"I am so far from home," he told her. "You can't know what that is like." She couldn't know how hard his life was, how it tried him. In 
none of his languages he spoke was there a word as vivid as his loneliness, and she wouldn't even understand the pale approximations he could offer. (17)

Chin is on two different levels. Not only is he unable to express himself because what he perceives and feels himself perceiving cannot necessarily be translated into language, but he is also deprived of expression on a purely political level. When he speaks he becomes human, and when he becomes human he no longer is just labor force, an anonymous nonentity, but possibly a threat to other humans, a competitor, a rival. Ultimately he longs "to be safe, to speak freely, to speak loudly" (266).

Contrary to the conventional Western women's roles, Fowler's female protagonists are powerfully eloquent. Adelaide Dixon, the woman suffragist, uses words in order to change society. Her speech means action. She tours the American West, and lectures on female sexuality in backward mining camps and redneck logging communities. Whereas Chin, the man, is afraid to speak because speech renders him visible, puts him in danger, Adelaide is not afraid to speak. Her speech means strength. She speaks because she is not afraid. Chin, who falls in love with her, admires her for exactly the qualities that he at first dislikes. In the traditional Western paradigm, the talkative woman is the weak character who is pleading with the male hero not to go out and get shot by the "bad guy," but who of course is utterly helpless and inefficient. Here it is the Eastern Chinaman, who has the same prejudices against talkative women, but he learns to overcome them. Chin admires her for her brazenness, when she addresses a rowdy male crowd, but he also realizes that the 
qualities that he values in a woman are silence, subservience,

submissiveness, and obedience--the opposites of Adelaide's character:

She had something to say about everything. This is not an attractive female quality, probably not even in the white culture. In fact, there was something sexless in the unrestrained way she confided in him, not that he wanted it any other way. (238)

Adelaide's power with words cannot be underestimated. Adelaide's words ultimately change Chin's way of thinking about women's conditions in China as well as in America. He notices for the first time how small the cribs are that the Chinese slave girls live in. Because of Adelaide he learns to value women. Her speech performs its purpose: at the end of the novel, Chin knows that he will honor his future wife because of Adelaide, and he will let his daughters grow up big-footed (286).

It is significant that, although Adelaide seems to be at ease with Chin, and readily confides in him, she is unable to express her feelings for him in words. Their last conversation is characterized by misunderstandings. She is averting her face, seeking refuge in a behavioral code typical for nineteenth century women. Adelaide, who can lecture publicly about the private issue of female orgasm, is unable to come to terms with her own sexuality, her longings, and desires. She self-critically examines her abilities:

A woman who couldn't hold an audience, was afraid to have children, was afraid to fall in love (...) Adelaide was afraid that if she ever once allowed herself to feel the full range of her sexual desires, that this would be a need too great for any man. That these desires, once allowed to come to life, would never be silenced or satisfied again. Why were men's sexual needs so easily accommodated, when women's were so difficult? [my italics] (228) 
Adelaide expresses a popular fear. Woman, the frightfully Other, the "dark continent" to speak in Freudian terms, is sexually insatiable. What is interesting here however is that it is the woman who speaks of her fear that once her body recognizes its needs it will never cease asking for more. The notion of the body-discourse which can no longer be silenced but has to be heard, parallels what goes on in the other discourse layers. Stories are being told all the time, it really is a matter of listening.

Fowler seems to agree with Northwest novelist Ursula K. LeGuin that "Story is our nearest and dearest way of understanding our lives and finding our way onward" (6). 39 Through stories we understand the world, and through dialogue of some form or another we make sense of our fellow creatures. Her novel Sarah Canary does away with the one-plot, one-character line, but instead offers a multitude of stories that intersect, talk to each other, change their course, and grow into new and different stories. The newspaper clippings of contemporary America connects the present to the past, the Chinese story complements the European fairy tale, the Indian folk story responds to the story of the suffragist. Even the knifes, keys and material objects talk. It is just a matter of listening. The readers of this novel understand through Chin, B.J., Adelaide, Tom, and Sarah Canary, that the story of the American West cannot be told in one voice: that it takes a multivocal canon to celebrate the diversity of the people of the West. Each voice is distinct, each voice has a place in the canon. Singing the dominant theme of the male Anglo-American conquest of the American West out of tune Sarah Canary's song is beautiful, full-bodied, rich, and dynamic. 
Ultimately, the question remains whether one can really re-write the story of the Old West. If there is an endless supply of unheard stories that need to be told, then the "simple" act of story-telling becomes increasingly problematic. Who makes the choices? Who listens? The role of the storyteller diminishes in favor of the stories themselves. Stories are created out of stories. It is the reader, or perhaps the listener, who grows in importance because "without our listening, all the stories are the same story" (287). 


\section{CHAPTER IV}

\section{CONCLUSION: HOW TO LIVE IN THE WEST}

OR:

\section{HOW TO COMBINE THEORY WITH PRACTICE}

Molly Gloss' novel The Jump-Off Creek as well as Karen Joy Fowler's novel Sarah Canary take the act of re-writing Western history and literature seriously. Although the two novels take different approaches to their stories of the Old West, both novels were written from a strong feminist impulse to write the unheard voices of women and ethnic minorities into the history of the West. Gloss, who grew up reading traditional Western literature, initially wanted to write a genre Western featuring a strong and heroic woman as main protagonist. Stories of the Old West with independent, and heroic women characters as main protagonists are rare, Gloss discovered, and the few there are, are not always easily accessible. Reading and researching women's diaries of the West helped her find an "authentic" nineteenth century voice for Lydia Sanderson. Fowler's academic training is in Southeast Asian studies. While doing research on the Chinese population in the American West in the nineteenth century, she discovered that there are hardly any records on Chinese immigrants prior to the Chinese Exclusion Act in 1882. A historical paradox? How can one write a Chinese Exclusion Act, if no Chinese immigrants exist on paper? Fowler's curiosity was raised. One historical paradox led to another. Fowler is also interested in how 
historically powerful women, such as the early suffragist Victoria Woodhull, were ignored by mainstream historical discourse. Her suffragist character Adelaide Dixon is based on this historical foremother. Both authors then came to the re-writing of the Old West with feminist concerns.

Re-writing the history of the West in the late twentieth century however poses different challenges than it would have twenty years earlier. Feminist impulses in the early 1970s differed from feminist practices of the late 1980s and early 1990s. Poststructural theories which newly emerged in the late sixties and early seventies have since then considerably influenced contemporary theory and practice. To simplify a complex issue, post-structurtalist theories and feminist theories have much in common, in that both critical approaches stem from a distrust of the dominating cultural and political structures and power relations. Popular readings of these two theoretical approaches, often categorize poststructuralist theories as a-political, as destructive deconstruction of viable structures, whereas feminist criticism is often blamed for being overly polemic. I want to emphasize, that my gross oversimplification here serves to highlight a crucial theoretical question which surfaces when thinking about my contemporary Western novels about the Old West: How to deal with the theoretical dilemma of writing oneself into a history which has traditionally excluded women and other non-representational groups such as ethnic minorities or mentally disturbed, and at the same time acknowledging that the concept of history is a construction? What are the consequences of this theoretical dilemma? Does a deconstruction of the concept of history mean that historical events such as the Massacre 
at Wounded Knee in 1890, or the Chinese Exclusion Act of 1882, or the Homesteading Act of 1865 did not really take place, that they are just texts? Or does it rather mean that so-called historical events are "competing and conflicting representations and meanings" in a assembly of historical texts, as Linda Hutcheon and other poststructuralists want to argue? 40 And does it not further suggest that these competing and conflicting representations and meanings ask for numerous critical and self-conscious interpretations? What Nietzsche, Sontag, and later deconstructors like Peterson argue is that we need new names, a "new historicity," (Peterson 984). We need to create a "new thing" which enables us to see the narrativity of history and acknowledges at the same time the need to write oneself into a history that has excluded women and ethnic minorities.

Gloss and Fowler both tackle the act of re-vision, of seeing with fresh eyes, self-consciously and self-critically. Their individual approaches to rewriting Western history and literature is different however. Whereas Gloss works within the paradigm of Western literature, taking the conventions of the Western plot of the cattle round-up, the marauding grizzly, and the cattle rustling cowboys as referents points to spin off her "new" narrative, Fowler questions Western literature from the outside, making the act of storytelling the central focus of her novel. In her story, the themes of Western literature are mutated into a myriad of different stories.

Gloss, then, works within the boundaries, the staked out fences of the Western literary territory, only to stretch these boundaries until the old fences are no longer stable. Throughout her novel Gloss emphasizes the crossing over of fences--the fences of the land as well as the fences of the 
mind. Her characters are submitted to a series of reversals. Whereas the traditional literature of the Old West dealt with rugged individualism, Gloss draws a Western picture in which men and women depend on each other for daily survival. In Gloss's novel, the characters have to learn how to communicate with each other, how to collapse the inner and outer fences. Lydia, the woman protagonist, is as much subjected to adjusting to a life in a rapidly changing West as Tim and Blue are. The men have to ask Lydia for help, and Lydia has to prove to be multi-talented: she takes turns being a cattle rancher, a surgeon, and a farmer. Community-making and acts of neighborly kindness are at the center of the woman's story. These themes spill over into the territory of the men's story. Lydia's diary entries connect her to the past and her historical present. For the readers, these diary entries connect Gloss's novel to a female Western tradition. With the inclusion of Lydia's private voice into the public narrative, Gloss makes a strong statement about the history and story of the Old West. Western history cannot exist without these personal voices and interpretations.

Fowler's novel attempts the task of re-writing the Old West differently. By placing her main focus on the act of storytelling itself, Fowler questions the concept of a one-dimensional Western history and story. She unbalances canonical Western literature, but instead of falling into the void and despairing over the possibility to re-write history, she offers alternative stories, alternative voices in the multi-vocal canon of Western American literature. Rather than "destroying" Western literature, she shows the readers that stories do not exist in a vacuum, but are created in response to other stories, live in dialogue with stories of the past and the 
future. The Native American folktale, the Chinese fable, the EuroAmerican fairy tale are all part of the endless variety of stories that can be told. Similar in theme, they nevertheless tell distinct tales about distinct cultures.

Fowler's narrative is more easily categorized as postmodern, because her pre-chapters not only establish connections between events of the past and events in the present, linking themes of racism and sexism across boundaries of culture and time, but also because these pre-chapters function as deconstructive disruptions, subverting the notion of a linear narrative. Fowler's narrative of gaps and random indeterminacies points toward the fragmented nature of Western history, in which conflicting and competing representations exist side by side.

Fowler's and Gloss's novels create "new" things out of old paradigms. They collapse the artificial boundaries between theory and practice in that they creatively write a poetics of Western history. The narrative strategies of the diary entries as well as the pre-chapters link the practice of living in the Old and New West to the theory of the West. Theory and practice are not two diametrically opposed concepts, but part of the same discourse. Nietzsche and Sontag have foregrounded theoretically what Fowler and Gloss are doing practically: they are creatively changing the West by contributing to a poetics of culture in which conflicting concepts of history, fiction and revision are in dialogue with each other. To create new names for familiar phenomena changes the nature of these phenomena. If one thinks, for example, of a historical event called the "Battle" of Wounded Knee in 1890, then changing the name to "Massacre" of Wounded Knee opens the door to a whole new representation of this historical event. The 
term "massacre" denies the notion of two opposing parties fighting against each other in battle, but implies that one party did not even have the chance or power to defend itself: close to three-hundred Native Americans were massacred indeed. Once the new name is coined, there is no going back to the old concept. There is no way one can still think about the event at Wounded Knee as a "battle."

After reading Gloss's and Fowler's novels it is impossible to think about the American West in terms of cowboys, shoot-out plots and violence only. The West has changed, because it now inhabits the stories of Chin and B.J., Tim and Lydia, Sarah Canary and Adelaide. At the end of the twentieth century, two women writers are actively contributing to an imaginative process of re-vision in which theory is manifested in practice. 
NOTES

Preface:

1 The title is borrowed from Alison Baker's short story of the same title, anthologized in Circle of Women. An Anthology of Contemporary Western Women Writers.

\section{Chapter I:}

2 By "West" I mean the American West as geographical place, roughly speaking the Western American states, as well as the psychological, mental space. For a good definition of these conflicting concepts of the West see Eric Heyne's Desert, Garden, Margin, Space. Literature on the American Frontier. Heyne distinguishes between an axis of utility and a spatial axis. He claims that the West is defined in oppositions of contrary terms (3).

3 I am conscious of the fact that to talk about poststructuralist thought means to generalize about and simplify a very diverse critical field. What I mean here is an overall skepticism towards the acceptance of meta-narratives, meta-histories as put forth by postmodern critics such as Jean-François Lyotard, Frederic Jameson and others. Poststructural criticism looks at the available structures only to deconstruct them. See Derrida's notion of decentering the centers. I am also aware of the difference between the terms "poststructural" and "postmodern," the first referring more to a theoretical bend coming right out of a structural, linguistic direction, the latter more to an overall cultural phenomenon resulting from poststructural theories. For a valuable discussion of these terms see John Carlos Rowe's "Postmodernist Studies" in Redrawing the Boundaries: The Transformation of English and American Literary Studies, 179-209.

4 See "Trends in Western Women's Writing" in A Literary History of the American West in which the emergence of a new women's Western literature is attributed to various factors: the publication of so-called "private writings", such as journals, diaries, letters, and oral histories, and the re-publication of older women's writing, both of which informs women's writing about the Old West today (1178-81). 
5 Ironically, the Marlboro cigarette was first targeted at women in 1928 , and was not a success. The company only changed its image later.

6 See chapter "Mary Jemison and Rebecca Boone: At Home in the Woods," in Kolodny's The Land Before Her: Fantasy and Experience of the American Frontiers, 1630-1860 for the threat of Indianization in early American captivity narratives.

7 See Frederick Jackson Turner's essay "The Significance of the Frontier for American History":

In short, at the frontier the environment is at first too strong for the man. He must accept the conditions which it furnishes, or perish, and so he fits himself into the Indian clearings and follows the Indian trails. Little by little he transforms the wilderness, but the outcome is not the old Europe, not simply the development of Germanic germs, any more than the first phenomenon was a case of reversion to the Germanic mark. The fact is, that here is a new product that is American (201).

8 See St. John De Crèvecoeur's Letters from an American Farmer anthologized in The Heath Anthology of American Literature. Volume One. Interestingly enough De Crèvecoeur was an outsider, a Frenchman in America.

9 See introduction to Folsom's study The Western: A Collection of Critical Essays, for a contextualization of Turner's and Smith's theories about the West as agrarian and utopian place for rebirth. Folsom distinguishes between the progressive and the primitivist approach to the study of the West. The progressive attitude, he claims, sees the value of the West in its rapid civilization and Easternization, the primitivist attitude sees the West as agrarian retreat, as pastoral paradise whose resources have to be saved.

10 Quoted in Forrest G. Robinson's essay "The New Historicism and the Old West," 89-90.

11 For a useful discussion of the various feminist critical theories see Catherine R. Stimpson's discussion of "Feminist Criticism" in Redrawing the Boundaries, 251-271. 
12 See Kolodny's The Land Before Her. She claims that women dreamed more about "locating a home and a familial human community within a cultivated garden" (xiii).

13 My understanding of theoretical methodology has been greatly influenced by reading Michel Foucault's chapter on "Method" in his The History of Sexuality in which he states:

In a specific type of discourse on sex, in a specific form of extortion of truth, appearing historically and in specific places (...) what were the most immediate, the most local power relations at work? How did they make possible these kinds of discourses, and conversely, how were theses discourses used to support power relations? How was the action of theses power relations modified by their very exercise, entailing a strengthening of some terms and a weakening of others, with effects of resistance and counterinvestments, so that there has never existed one type of stable subjugation, given once and for all? How were these power relations linked to one another according to the logic of a great strategy, which in retrospect takes on the aspect of a unitary and voluntarist politics of sex? (97)

I am also indebted to Arnold Krupat's recent study Ethnocriticism. Ethnography, History, Literature. in which he locates a criticism that is committed to a movement between grounds, "a critical discourse which claims to be both on and of the frontier, traversing middle ground while aspiring to a certain centrality, descriptive and normative at once (...)" (29). Krupat's use of the term 'frontier' is significant, because he does not mean Turner's frontier in the sense of a receding line, but rather James Clifton's frontier as "culturally defined place where people of different culturally expressed identities meet and deal with one another" (Clifton, 24).

It seems to me that what I am attempting to do, mainly to create a dialogue between the different theoretical positions, is what Krupat is aiming at in his study of Native American discourses. Krupat's theory is heavily influenced by Bakhtinian theories of the dialogical nature of language.

14 See for example Vera Norwood's essay "Crazy-Quilt Lives: Frontier Sources for Southwestern Women's Literature" in which she refutes the notion of a domestic garden in view of a unfruitful Southwestern desert landscape that resists gardening (94). A more fundamental criticism on the study of western women's history is stated in 
Rosalinda Mendez Gonzalez' article, "Distinctions in Western women's experience: Ethnicity, Class and Social Change," in which the author claims that studying only the written sources of women's western lives means privileging one particular class of women: literate women. Gonzalez argues for a new approach to women's western history, in which new sources such as oral histories are studied (239). See also Elizabeth Jameson's essay "Women as Workers, Women as Civilizers: True Womanhood in the American West" (147). Both articles appeared in The Women's West.

15 Limerick is not the only one to revise the history of the West. Numerous regional scholars studied very specific regions of the West. Milton and Athearn, for example, analyzed the impact of the official closing of the frontier in 1890 by Frederick Jackson Turner's consensus theory on the Western states of the Rocky Mountains and Great Plains. They claimed that the closing of the official frontier meant an opening in regional studies. See John Milton The Novel of the American West, and Robert G. Athearn The Mythic West in Twentieth Century America.

16 See Louis Montrose's "New Historicisms" for a valuable discussion of the field in Redrawing the Boundaries, 392-419.

17 See for example the popularity of science fiction stories, in which the frontier is moved into outer space. The latest frontier is the frontier of cyberspace, where one can invent one's own borders. In a recent PBS series on cyberspace, traditional metaphors such as "Wild West," "frontier" were applied to talking about the boundless possibilities that internet has to offer.

18 See Edward Said's discussion of the romanticizing of the Other in his influential study Orientalism, in which he talks about the necessity of the Other to define the self. Similarly, the West has become the safety valve for the East, in symbolizing at the same time the true America and the savage wilderness.

19 See Tompkins's chapter on "Death," in which she claims that the Western is a direct reaction against the nineteenth century domestic novel and what the domestic novel symbolizes, the Cult of True Womanhood (38-40). See also her chapter on "Women and the Language of Men," in which she argues that the traditional Western is anti-language, associating women with language, culture, and religion, men with action and silence. In traditional Westerns the power relationship between men and women is clear: men are powerfully silent, women talkative and powerless (47-67). 


\section{Chapter II:}

20 This quote is taken from Rudolfo A. Anaya's short story $B$. Traven is Alive and Well in Cuernnavaca anthologized in Prose and Poetry of the American West, 689-703.

21 There are several important exceptions to this exclusion of women writers from Western literature: the famous Willa Cather, and the less famous but albeit important Mary Austin, Mari Sandoz, Dorothy Johnson, Gertrude Atherton, and Mildred Walker, to name a few. There is also a great number of more obscure women writers who wrote Western dime novels at the end of the nineteenth and beginning of the twentieth century. Women writers of the West have been rediscovered in recent years, a fact, which is reflected not only in the re-edition of older works, but also in the publication of contemporary Western fiction by women. See for example a new anthology of contemporary Western women writers: Circle of Women: An Anthology of Contemporary Western Women Writers.

22 I am using part of Patricia Nelson Limerick's title here, referring to her essay "Making the Most of Words. Verbal Activity and Western America" which is anthologized in Under an Open Sky: Rethinking America's Western Past.

23 The heroines of Western dime novels written by women at the end of the nineteenth century are often highly melodramatic characters, who in the end fall for the traditional love-plot. Lydia Sanderson decidedly differs from these popular Western models of female behavior, and also from the female cardboard characters of most male Western fiction. Lydia Sanderson is closest to female characters created by serious Western women writers such as Willa Cather, Mari Sandoz, Mary Austin, and others.

24 Rosalinda Mendez Gonzalez gives a Marxist critique of the Homesteading Act in her article "Distinctions in Western Women's Experience: Ethnicity, Class and Social Change," claiming that "The Homestead Act of 1862 (...) forced individuals and individual families to settle independently; no land was made available for whole communities" (244). Elizabeth Jameson in her article "Women as Workers, Women as Civilizers: True Womanhood in the American West" points to problematic notions of the West as liberating place, which reminds one of the Turnerian notion of a peaceful westward progression. 
25 The cliche of the "reluctant pioneer" is expressed in literature. See for example E. D. Rølvaag's pioneer novel Giants in the Earth, in which the male character Per Hansa is the enthusiastic pioneer who believes in progress and the westward expansion, and his wife Beret almost loses her mind over the lonesome frontier life on the Great Plains. She longs for the familiar home back East.

26 In Gloss's novel the act of mothering/civilizing is problematized. When Lydia first arrives at her cabin for instance, it is inhabitated by adolescent cowboys, who immediately pack their things when she claims the cabin. Her offer to stay the night, is politely refused. They refuse to be mothered by her. Likewise, Lydia refuses to mother or civilize the brat Harley later on, when he requests to stay the night.

27 See Patricia Nelson Limerick in "Making the Most of Words: Verbal Activity and Western America," 178.

28 In early revisionist Western women's history, diaries were studied as a major research source, see for example Lilian Schlissel's Women's Diaries of the Westward Journey. This methodological approach was later criticized by scholars such as Gonzalez and Jameson who claim that women's diverse western hisrories are in need of new, more diverse sources, such as oral history.

29 This term is taken from Carl A. Brehdal's essay : "Divided Narrative: Mary Austin and Sherwood Anderson" in New Ground: Western American Narrative and the Literary Canon, where he claims that a divided narrative is the result "of an imaginative effort to respond openly to space." (49) Unlike Brehdal, I see Gloss's divided narrative as a combination of responding to space and to gender specific interpretations of the West.

$30 \mathrm{He}$ argues in his article "The Jump-Off Creek: Molly Gloss' Novel of Frontier Manners" that "where these two stories "impinge" upon each other, (...) at theses points of convergence where social convention, the lack of social convention within this unique landscape becomes apparent" (129).

31 See Gregory Morris's essay: "The Jump-Off Creek: Molly Gloss' Novel of Frontier Manners:" where he suggests that "communication (...) 
is marked by disjuncture and severance; speech is broken, incomplete (...) (129).

Chapter III:

32 See Frederick C. Luebke's article "Ethnic Minority Groups in the American West." in Historians and the American West, 386-388.

33 This strategy of turning the outsiders into the heroes of the West was already employed by Bret Harte in his early Western story "The Outcasts of Poker Flat" anthologized in Stories of the Old West, 26-36.

34 See the Chinese Exclusion Act of 1882, which tried to stop the influx of Chinese workers in Limerick's The Legacy of Conquest, 259-277.

35 See Edward Said's influential study in Orientalism.

36 See Leslie Fiedler. The Return of the Vanishing American, in which he claims that madness is the last frontier, namely the frontier of the mind; also see Ken Kesey's One Flew Over the Cuckoo's Nest; also see Sandra M. Gilbert and Susan Gubar's pathbreaking study The Madwoman in the Attic: The Woman Writer and the Nineteenth-Century Literary Imagination, which posits that there is a female literary tradition which uses madness and insanity as feasible construction to escape the confinements of patriarchal discourse.

37 See Adrienne Rich in a 1991 interview with David Montenegro: "tension between the possiblities in language for mere containment and the possiblities for expansion, for liberation" in Adrienne Rich: Poetry and Prose. A Norton Critical Edition, 258.

38 See Adrienne Rich on the power of language in her interview with David Montenegro, 258.

39 Ursula K. LeGuin. "The Stories We agree to Tell." New York Sunday Times Book Review, 12 March 95, 6.

Chapter IV: 
40 quoted from Linda Hutcheon's The Politics of Postmodernism, cited in Nancy J. Peterson's important article "History, Postmodernism, and Louise Erdrich's Tracks," 984. 


\section{BIBLIOGRAPHY}

Ahearn, Kerry. "The Rural and the Urban in Oregon Literature." Oregon Humanities (Winter, 94): 34-39.

Ananya, Rudolfo A. B. Traven is Alive and Well in Cuernavaca. Prose and Poetry of the American West. Ed. James C. Work. Lincoln; London: U of Nebraska P, 1990. 689-703.

Armitage, Susan, and Elizabeth Jameson, eds. The Women's West. London: U of Oklahoma Press, 1987.

Athearn, Robert G. The Mythic West in Twentieth-Century America. Lawrence: UP of Kansas, 1986.

Attridge, Derek, Geoff Bennington, and Robert Young, eds. Post-structuralism and the Question of History. Cambridge: Cambridge UP, 1987.

Baker, Alison. "How I came West and Why I Stayed." Circle of Women. An Anthology of Contemporary Women Western Writers. Eds. Mary Clearman Blew, and Patricia Henley. New York: Penguin Books, 1994.

Baym, Nina. "Melodramas of Beset Manhood: How Theories of American Fiction Exclude Women Authors." The New Feminist Criticism. Essays on Women, Literature, and Theory. Ed. Elaine Showalter. New York: Pantheon Books, 1985.

Bell, F. A., D. K. Adams, and Eric Mottram, eds. American Literary Landscapes: The Fiction and the Fact. New York: St. Martin's Press, 1988.

Brehdal, A. Carl. New Ground: Western American Narrative and the Literary Canon. Chapel Hill: U of North Carolina P, 1989.

Cawelti, John G. The Six-Gun Mystique. 2nd ed. Bowling Green: Bowling Green State U Popular P, 1984.

Eliot, Thomas Stearns. The Complete Poems and Plays, 1900-1950. New York: Harcourt and Brace, 1952. 
Erben, Rudolf. "After Turner and Smith: Recent Interpretations of the American West as Symbol and Myth." Arbeiten aus der Anglistik und Amerikanistik 18.1 (1993): 23-36.

Etulian, Richard W. "Shifting Interpretations of Western American Cultural History." Historians and the American West. Ed. Michael P. Malone. Lincoln; U of Nebraska P, 1983.

Fender, Stephen. Plotting the Golden West. American Literature and the Rhetoric of the California Trail. London: Cambridge UP, 1981.

Fiedler, Leslie A. The Return of the Vanishing American. New York: Stein and Day Publishers; Toronto: Saunders of Toronto Ltd., 1968.

Folsom, James K. The Western. A Collection of Critical Essays. Twentieth Century Views. Englewood Cliffs, N.J.: Prentice Hall Inc., 1979.

Foucault, Michel. Madness and Civilization. A History of Insanity in the Age of Reason. New York: Vintage Books, 1988.

--. The History of Sexuality: An Introduction. New York: Pantheon Books, 1978.

Fowler, Karen Joy. Sarah Canary. New York: Henry Holt and Company, 1991.

Fraser, Nancy, and Linda Nicholson. "Social Criticism without Philosophy: An Encounter between Feminism and Postmodernism." Universal Abandon. The Politics of Postmodernism. Ed. Andrew Ross. Minneapolis: U of Minnesota Press, 1988.

Gates, Henry Louis, Jr. "The Master's Pieces: On Canon Formation and the African-American Tradition." The Politics of Liberal Education. Eds. Darryl J. Gless, and Barbara Herrnstein Smith. Durham: Duke University Press, 1992. 94-117.

Gilbert, Sandra M., and Susan Gubar. The Madwoman in the Attic.:The Woman Writer and the Nineteenth-Century Literary Imagination. New Haven: Yale University Press, 1979.

Gloss, Molly. The Jump-Off Creek. Boston: Houghton Mifflin Company, 1989.

Gonzalez, Rosalinda Mendez. "Distinctions in Western Women's Experience: Ethnicity, Class, and Social Change." The Women's West. Eds. Susan 
Armitage, and Elizabeth Jameson. Norman; London: U of Nebraska P, 1987. 237-253.

Heyne, Eric, ed. Desert, Garden, Margin, Range. Literature on the American Frontier. New York: Twayne Publishers; Toronto: Maxwell Macmillan Canada, 1992.

Hutcheon, Linda. The Politics of Postmodernism. London; New York: Routledge, 1989.

Jameson, Elizabeth. "Women as Workers, Women as Civilizers: True Womanhood in the American West." The Women's West. Eds. Susan Armitage, and Elizabeth Jameson. Norman; London: U of Nebraska P, 1987. 145-165.

Jensen, Billie Barnes. "'In the Weird and Wooly West': Anti-Suffrage Women, Gender Issues, and Woman Suffrage in the West." Journal of the West 32.3 (July, 93): 41-51.

Kellner, Hans. Language and Historical Presentation: Getting the Story Crooked. Madison: U of Wisconsin P, 1989.

Kolodny, Annette. "Letting Go of Our Grand Obsessions: Notes toward a New Literary History of the American Frontiers." American Literature 64.1 (March, 1992): 1-19.

--. The Land Before Her: Fantasy and Experience of the American Frontiers, 16301860. Chapel Hill; London: U of North Carolina P, 1984.

--. The Lay of the Land. Metaphor as Experience and History in American Life and Letters. Chapel Hill: University of North Carolina Press, 1975.

Krupat, Arnold. Ethnocriticism: Ethnography, History, and Literature. Berkeley: U of California P, 1992.

LeGuin, Ursula K. "The Stories We Agree to Tell." New York Sunday Times Book Review, 12 March 95, 6.

Limerick, Patricia Nelson. "Making the Most of Words. Verbal Activity and Western America." Under an Open Sky. Rethinking America's Western Past. Eds. William Cronon, George Miles, and Jay Gitlin. New York; London: W.W. Norton, 1992. 167-185. 
---. The Legacy of Conquest: The Unbroken Past of the American West. New York: Norton, 1987.

Luebke, Frederick C. "Ethnic Minority Groups in the American West." Historians and the American West. Ed. Michael P. Malone. Lincoln; London: U of Nebraska P, 1983. 387-405.

Malone, Michael P., and Richard W. Etulian. The American West: A Twentieth Century History. Lincoln; London: U of Nebraska P, 1989.

Marx, Leo. The Machine in the Garden: Technology and the Pastoral Ideal in America. New York: OUP, 1964.

Meldrum, Barbara Howard, ed. Old West-New West: Centennial Essays. Moscow, Idaho: U of Idaho P, 1993.

--. Under the Sun: Myth and Realism in Western American Literature. Troy, NY.: Whitston Publ. Company, 1985.

Milner II, Clyde A. , Carol A. O'Connor, and Martha A. Sandweiss, eds. The Oxford History of the American West. New York; Oxford: OUP, 1994.

Milton, John R. The Novel of the American West. Lincoln: U of Nebraska Press, 1980.

Mogen, David, Mark Brusby, and Paul Bryant, eds. The Frontier Experience and the American Dream. Essays on American Literature. College Station: Texas A and M UP, 1989.

Morris, Gregory L. "The Jump-Off Creek: Molly Gloss' Novel of Frontier Manners." South Dakota Review 30.2 (Summer, 92): 128-42.

Morris, Gregory L. Talking up a Storm: Voices of the New West. Lincoln; London: U of Nebraska P, 1994.

Nietzsche, Friedrich. The Gay Science. With a Prelude in Rhymes and an Appendix of Songs. Transl. Walter Kaufmann. New York: Vintage Books, 1974.

Norwood, Vera. "Crazy-Quilt Lives: Frontier Sources for Southwestern Women's Literature."The Desert is no Lady: Southwestern Landscapes in 
Women's Writing and Art. Eds. Vera Norwood, and Janice Monk. New Haven: Yale UP, 1987.

Peterson, Nancy J. "History, Postmodernism, and Louise Erdrich's Tracks." PMLA 109.5 (October, 94): 983-994.

Rich, Adrienne. Adrienne Rich. Poetry and Prose. A Norton Critical Edition. Eds. Barbara Charlesworth Gelpi, and Albert Gelpi. New York: W. W. Norton, 1993.

Ross, Nancy Wilson. Westward the Women. San Francisco : North Point Press, $1944 ; 1985$.

Said, Edward W. Orientalism. New York: Vintage Books, 1979.

Santayana, George. The Genteel Tradition. Nine Essays. Ed. Douglas L. Wilson. Cambridge: Harvard UP, 1967.

Schlissel, Lilian. Women's Diaries of the Westward Journey. New York: Schocken Books, 1982.

Slotkin, Richard. Gunfighter Nation: The Myth of the Frontier in twentieth-century America. New York: Harper Perennial, 1993.

---. Regeneration Through Violence: The Mythology of the American Frontier, 16001860. Middletown: Wesleyan UP, 1973.

--. The Fatal Environment: The Myth of the Frontier in the Age of Industrialization. New York: Antheneum, 1985.

Smith, Henry Nash. Virgin Land: the American West as Symbol and Myth. New York: Vintage Books, 1957.

---. "Symbol and Idea in Virgin Land." Ideology and Classic American Literature. Eds. Sacvan Bercovitch, and Myra Jehlen. London: Cambridge UP, 1986.

Sontag, Susan. "Against Interpretation." A Susan Sontag Reader. Ed. Elizabeth Hardwick. New York: Vintage Books, 1983. 95-105. 
St. John De Crèvecoeur, Hector J. Letters from an American Farmer. The Heath Anthology of American Literature. Volume One. Eds. Paul Lauter et al. Lexington, Mass. : D. C. Heath \& Co., 1994.

Stimpson, Catherine. "Feminist Criticism." Redrawing the Boundaries. The Transformation of English and American Literary Studies. Eds. Stephen Greenblatt, and Giles Gunn. New York: MLA, 1992.

Taylor, Golden L. et al., eds. A Literary History of the American West. Fort Worth: Texas Christian UP, 1987.

Tompkins, Jane. "Indians': Textuality, Morality and the Problem of History." Critical Inquiry 13.1 (Autumn, 1986): 101-119.

--.. West of Everything. The Inner Life of Westerns. New York; Oxford: OUP, 1992.

Turner, Frederick Jackson. "The Significance of the Frontier for American History." Ed. Harold P. Simonson. New York: Ungar, 1963.

Voloshin, Beverly R., ed. American Literature, Culture, and Ideology: Essays in Memory of Henry Nash Smith. New York: Peter Lang, 1990. 